\title{
The End of ODA (II): The Birth of Hypercollective Action
}

\section{Jean-Michel Severino and Olivier Ray}

\section{Abstract}

The development business has become much more complex in the past decade, with actors proliferating and collaboration fragmenting. This trend is characteristic of the change from collective action to what the authors term hypercollective action. Such a shift brings new energy and resources to international development, but also more difficulty managing global public policy. Severino and Ray use the lessons of the Paris Declarationthe first large-scale effort to coordinate hypercollective action—as a starting point for envisioning a new conceptual framework to manage the complexity of current international collaboration. They offer concrete suggestions to improve the management of global policies, including new ways to share information, align the goals of disparate actors, and create more capable bodies for international collaboration. 


\title{
The End of ODA (II): The Birth of Hypercollective Action
}

\author{
Jean-Michel Severino
}

Olivier Ray

Jean-Michel Severino is a former CEO of the Agence Française de Développement (AFD). He chairs the French Partnership for Water (FPW), is a member of the French Académie des Technologies and a senior fellow of the Fondation pour la Recherche Economique Internationale (FERDI). Olivier Ray is a staff member and researcher at AFD.

CGD is grateful for contributions from the Swedish International Development Agency in support of this work.

Jean-Michel Severino and Olivier Ray. 2010. "The End of ODA (II): The Birth of Hypercollective Action.” CGD Working Paper 218. Washington, D.C.: Center for Global Development. http://www.cgdev.org/content/publications/detail/1424253

Center for Global Development 1800 Massachusetts Ave., NW Washington, DC 20036

202.416 .4000

(f) 202.416 .4050

www.cgdev.org
The Center for Global Development is an independent, nonprofit policy research organization dedicated to reducing global poverty and inequality and to making globalization work for the poor. Use and dissemination of this Working Paper is encouraged; however, reproduced copies may not be used for commercial purposes. Further usage is permitted under the terms of the Creative Commons License.

The views expressed in this paper are those of the author and should not be attributed to the board of directors or funders of the Center for Global Development. 


\section{Contents}

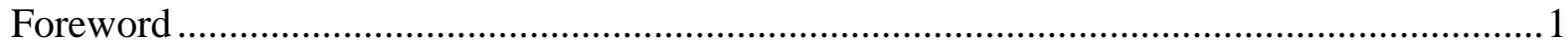

Summary

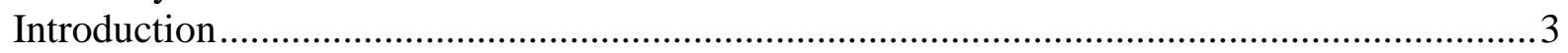

1.1 An institutional jungle........................................................................................

The demographic surge of global public finance................................................................. 7

Privatizing international cooperation... with public support................................................. 8

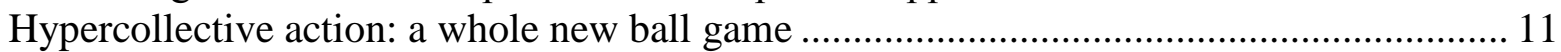

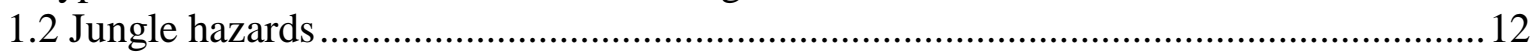

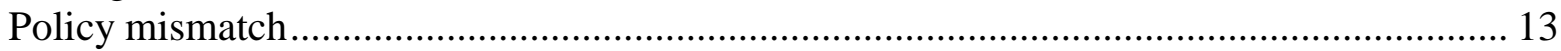

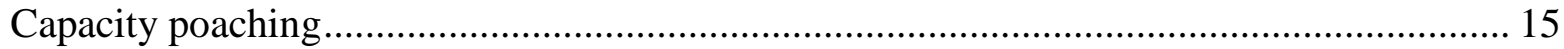

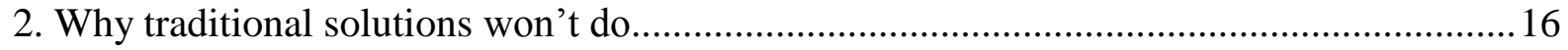

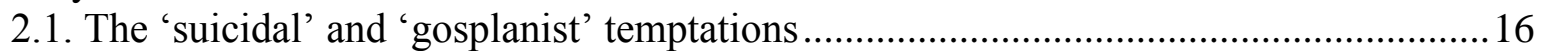

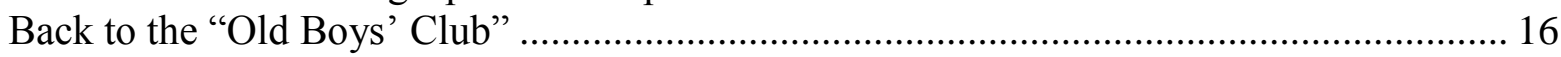

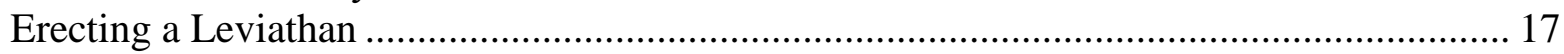

2.2 The Paris Declaration: too much, too little? ................................................................. 19

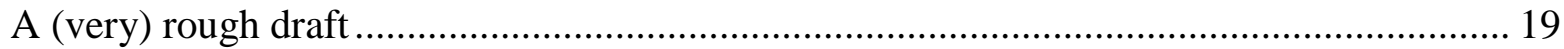

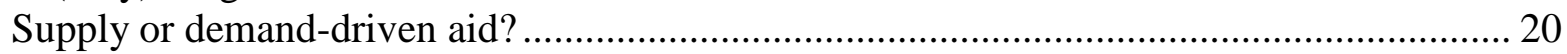

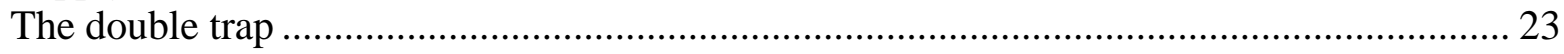

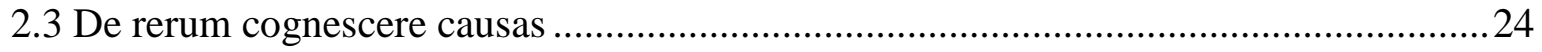

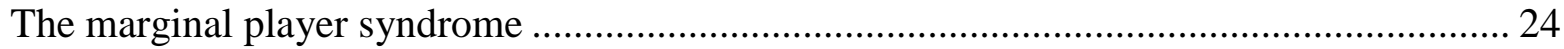

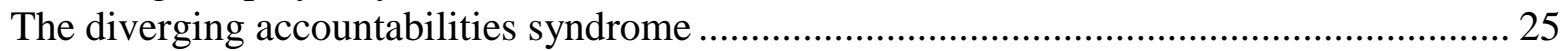

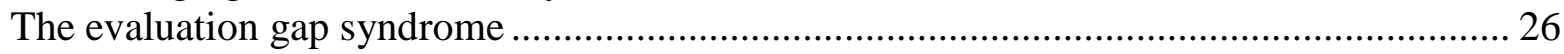

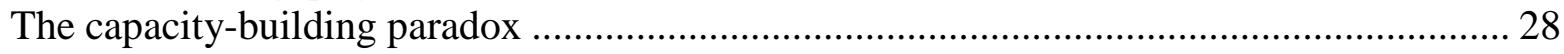

3. Engineering processes of hypercollective action ………..............................................29

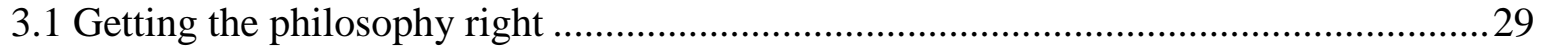

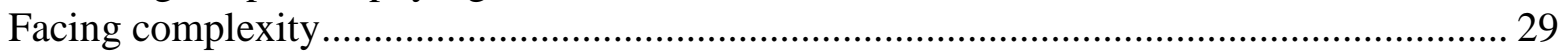

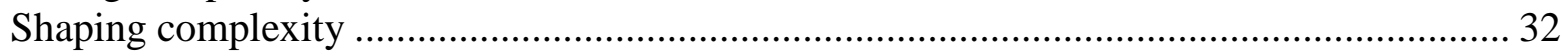

3.2 Addressing specific gaps in the market of global public policies....................................33

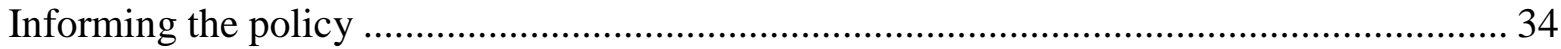

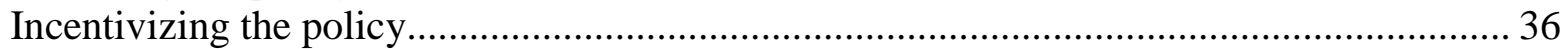

Generating common norms, standards and objectives...................................................... 41

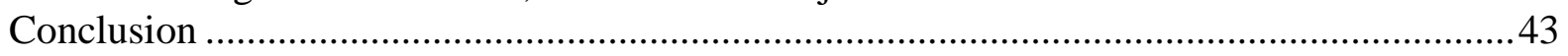





\section{Foreword}

INNOVATIONS IN AID PUBLICATION SERIES; End of ODA (II)

From its inception, the Center for Global Development has made its mark on issues of aid and aid effectiveness. Many of our staff and non-resident fellows-Owen Barder, Michael Clemens, William Easterly, Carol Lancaster, Ruth Levine, Todd Moss, Mead Over, David Roodman, Arvind Subramanian, and myself, too-have been key contributors to a lively debate on the question of whether and how aid and the aid system work.*

Though we normally include in our working paper and other series only analyses by CGD staff and non-resident fellows or analyses we commission ourselves for a particular program, in this special series we are pleased to publish from time to time at our discretion papers and essays prepared outside the Center. Our aim is to share more broadly otherwise unpublished work in which authors propose new thinking about aid and the aid system and new approaches to operationalizing aid transfers. The focus will be on innovations-whether in ideas or operations.

Our goal is that the Innovations in Aid series speeds and broadens access to new ideas, and contributes to more effective aid programs-public and private, bilateral and multilateral, traditional and new donors.

In this paper, Jean-Michel Severino and Olivier Ray continue their re-evaluation of overseas development assistance. Here they argue that old architectures for global collaboration are not sufficient to handle the shift from collective action to today's 'hypercollective'action. They push for and new, more open and comprehensive framework and offer concrete suggestion to make that happen, including initiatives to share knowledge and evaluation, innovative sticks and carrots for governments and all civil society players to improve convergence; new generations of coalitions and clubs.

Nancy Birdsall

President

Center for Global Development

*http://www.cgdev.org/section/topics/aid_effectiveness 


\section{Summary}

The last decade has seen a radical transformation in the number and kind of actors involved in the development aid, international relief and global public goods industries - in both donor and recipient nations. This double trend of proliferation (i.e. the increase in the number of actors) and fragmentation (i.e. the scattering of donor activity) of international cooperation is characteristic of the shift from collective to 'hypercollective action'. While this evolution should be greeted with enthusiasm for the energy and additional resources it brings to global public policies, ${ }^{1}$ it carries important efficiency costs. In this paper, we argue that steering complexity towards efficiency is one of the prime challenges for the governance of global public policies in the decades to come.

The Paris Declaration is the first large-scale effort to harness the 'hypercollective' in the development aid ecosystem. As such, it provides important lessons on international coordination processes in the new era of hypercollective action. While it starts from a convincing diagnosis of the problems, its incantations for donors to do more and better reveals an imperfect analysis of their political economy. We argue that what is at stake in aid effectiveness is less the proliferation of actors (a trend that is here to stay) than the management of this proliferation in a way that addresses the faulty incentive structures of the actors of international cooperation. Four issues are in particular need of attention: the marginal player syndrome, the diverging accountability syndrome, the evaluation gap syndrome and the capacity-building paradox.

As a consequence, in spite of all its merits, the Paris Declaration does not provide solid enough ground on which to build the kind of hypercollective action that is required by the burgeoning global public policies: it focuses on local issues (thus losing sight of upstream incoherence); it assumes that donors are driven by a single preference function; it sees aid recipients as a homogeneous whole; and it relies excessively on two modes of collaboration (rules and standards).

We argue that it is high time for a new conceptual framework to emerge, one which will help shape dynamic processes of multi-actor convergence that are more compatible with the political economy of international cooperation initiatives as they are taking shape in these early years of the 21st century. Improving actors' performances in the delivery of their share of the collective good will imply building a more open and comprehensive framework of collaboration for the provision of global public services - one which draws on the five threads of cooperation (rules and agreements; norms and standards; systems of incentives; information and discourses; networks and partnerships). These reflections lead us to suggest a new ambition for multilateral organizations - becoming the agents of effective hypercollective action. It also leads us to suggest additional concrete steps which would improve the management of global policies, and specifically global development finance. They include knowledge, information and evaluation initiatives, and notably an "IPCC" for development; innovative sticks and carrots for governments and all civil society players to improve convergence; new generations of coalitions and clubs.

\footnotetext{
${ }^{1}$ See next page for a definition of the terms 'global public policy'/ 'global public policies'.
} 


\section{Introduction}

In a previous paper ${ }^{2}$, we announced the end of Official Development Assistance (ODA) as we know it - the death of a policy born in the mid- $20^{\text {th }}$ century.

We showed that a new phoenix is rising from its ashes, and that this budding public policy, which links nations of the world in a variety of cooperative efforts, differs from its forebear in three important ways. First, its tasks go far beyond those of traditional development aid to address a larger set of global challenges. Secondly, its toolbox has itself expanded to include a whole range of financial and technical instruments ${ }^{3}$. Thirdly, the number and kind of actors who drive this global endeavour has surged. This third trait of official development assistance's troublesome offspring is generating a major governance conundrum for international policymakers. This governance conundrum is what the present paper seeks to address.

Building coherence among a highly fragmented array of players, each of whom driven by its own set of preferences and pursuing a great diversity of policy goals, is not just a fascinating intellectual challenge. It is an imperious necessity. Indeed, if the state of global governance can be gauged according to this embryonic international public policy, there are reasons to worry: the multiple costs of the field's fragmentation are such that they jeopardize the ability to meet the daunting challenges that lay before us. From world summit to donor conference, the efforts to coordinate international action lead to results incommensurate with the stakes they are designed to meet.

Despite multiplying signs of urgency, global undertakings to tackle global challenges continue to stumble upon policy incoherence, dispersion and free riding behaviour that plague their efficiency. The clear and relatively consensual identification of a public 'ill' (climate change, food insecurity, malaria, piracy...), the oftentimes impressive collective mastery of the tools needed to address it and the precise estimate of the means required to finance the effort flounder, at the stage of implementation, in the quicksand of collective action - or, as the number and diversity of stakeholders involved in these global endeavours have prompted us to rename it, 'hypercollective action'4. The disappointment of the December 2009 Copenhagen negotiations shows that it is no use mourning the foregone policy; the urgency lies in tending to the newborn ${ }^{5}$.

This paper aims to explore a new frontier of the emergent global public policy: designing effective processes of hypercollective action. It begins by describing the maelstrom that characterizes efforts of international cooperation, and asks what we should understand by 'coordination' when dealing with a constellation of actors moving in different directions and bereft of any overarching authority (1). It then examines some of the structural reasons why instances of coordination in the field of development assistance fail to address the root causes of policy incoherence (2). This analysis of the political economy of aid leads us to suggest a few

\footnotetext{
${ }^{2}$ SEVERINO, JM. and RAY, O. (March 2009), "The End of ODA: Death and Rebirth of a Global Public Policy" in Center for Global Development Working Paper, (167).

${ }^{3}$ On the shifting mandates of development policy, see also Nancy Birdsall, 'Reframing the Development Project for the 21st Century', keynote remarks at Conference on Building Our Common Future, DFID, March 2009.

${ }^{4}$ The concept of hypercollective action in the realm of international development was first explored in SEVERINO, JM. and CHARNOZ, O. (2008), De l'ordre global à la justice globale: vers une politique mondiale de régulation, vol. 2. En temps réels..

${ }^{5}$ This, of course, may require addressing hereditary diseases that risk affecting the new policy as it did the old. Many of the concerns expressed in the economic literature of the 1990's (the macroeconomic sustainability of projects and programs, the fungibility of resources, the negative side-effects of large financial transfers...) remain valid, and require continued investment.
} 
simple principles and concrete steps to forge the convergence processes that will lay the basis of a more efficient system of international cooperation (3).

\section{The quest for effective collective action}

The last ten to twenty years have seen a radical transformation in the number and kind of actors involved in the development aid, international relief and global public goods industries - in both donor and recipient nations. This sudden surge of players involved in the management of global interdependences has considerably enriched the ancient industry of official development assistance. It has dynamited old practices, bringing additional funding as well as new capacities.

But the strength of this emerging global policy is also its Achilles' heel. Its extreme fragmentation is a source of disorganisation that often verges on incoherence. While each actor brings an essential stone to the edifice, and while creativity and competition bring vital energy to the public policy, the latter's solidity will depend on their capacity to make their agendas and practices converge. Managing this bustling creativity is one of the prime challenges of global public policies for the years to come.

\section{'Global Public Policies' in the $21^{\text {st }}$ century}

The world of international cooperation is living challenging times in these early years of the $21^{\text {st }}$ century. In the space a decade, the world has had to face a structural security crisis revealed by the 9/11 attacks, a twin food and energy crisis, a mounting climate change threat, a global financial crisis and a series of deadly global pandemics - all of which are underpinned by a global social divide between those who have (health, wealth, mobility... 'capacity' ${ }^{\text {), }}$, and those who have not. Although none of them are new, the unprecedented combination of global challenges to the welfare of humanity is putting international collective action to the test.

These mounting global stakes have sparked an unprecedented boom in international cooperation initiatives. In the sound and the fury of diplomatic summits, NGO gatherings or local cooperation initiatives, the world is witnessing the gradual emergence of international policies that aim to provide for a variety of global public goods: collective security, international health, environmental protection, financial stability, food security, poverty reduction, open trade, etc ${ }^{7}$. Most of them are underpinned by financial transfers that aim to build the capacity of less developed nations tackle these issues of common interest. In the sense that they respond to citizens' demands for collective services, this new breed of global policies have much in common with the public policies that have emerged at the local, national or regional levels over the past centuries to tackle common welfare concerns. This is why, by analogy, we refer to them as 'Global Public Policies'.

However, they differ from national or regional public policies in at least two important ways. First, they are not exclusively 'public', as private actors play an important and increasing role in their elaboration and delivery. Second, the process through which they are devised and implemented is very different from the processes that generally gives rise to national policies. The present paper looks into the political economy of this global public policy-making process,

\footnotetext{
${ }^{6}$ Or 'capability', in the sense of Amartya Sen's 'capability approach'. SEN, A. (1992). Inequality Reexamined. Harvard University Press.

${ }^{7}$ See KAUL, I. Conceiçao, P., Le Goulven, K. and Mendoza, R.U (eds) (2003), Providing Global Public Goods: Managing Globalization. Oxford University Press. And Kaul, I., Grunberg, I. and Stern, M.A. (eds) (1999), Global Public Goods: International Cooperation in the $21^{\text {st }}$ Century, Oxford University Press.
} 
and analyses the reasons for some of its shortcomings. While new-generation development assistance is analysed as an instance of this complex policy-making process, we believe that many of the dynamics we describe apply to other global public policies.

In the same way that 'public policy' at a national level can both refer to specific policies (health, education, etc.) and more generically to public action, 'global public policies' refers to the set of thematic policies (such as international health, poverty-reduction or collective security) while 'the' global public policy is used more generically to describe international cooperation.
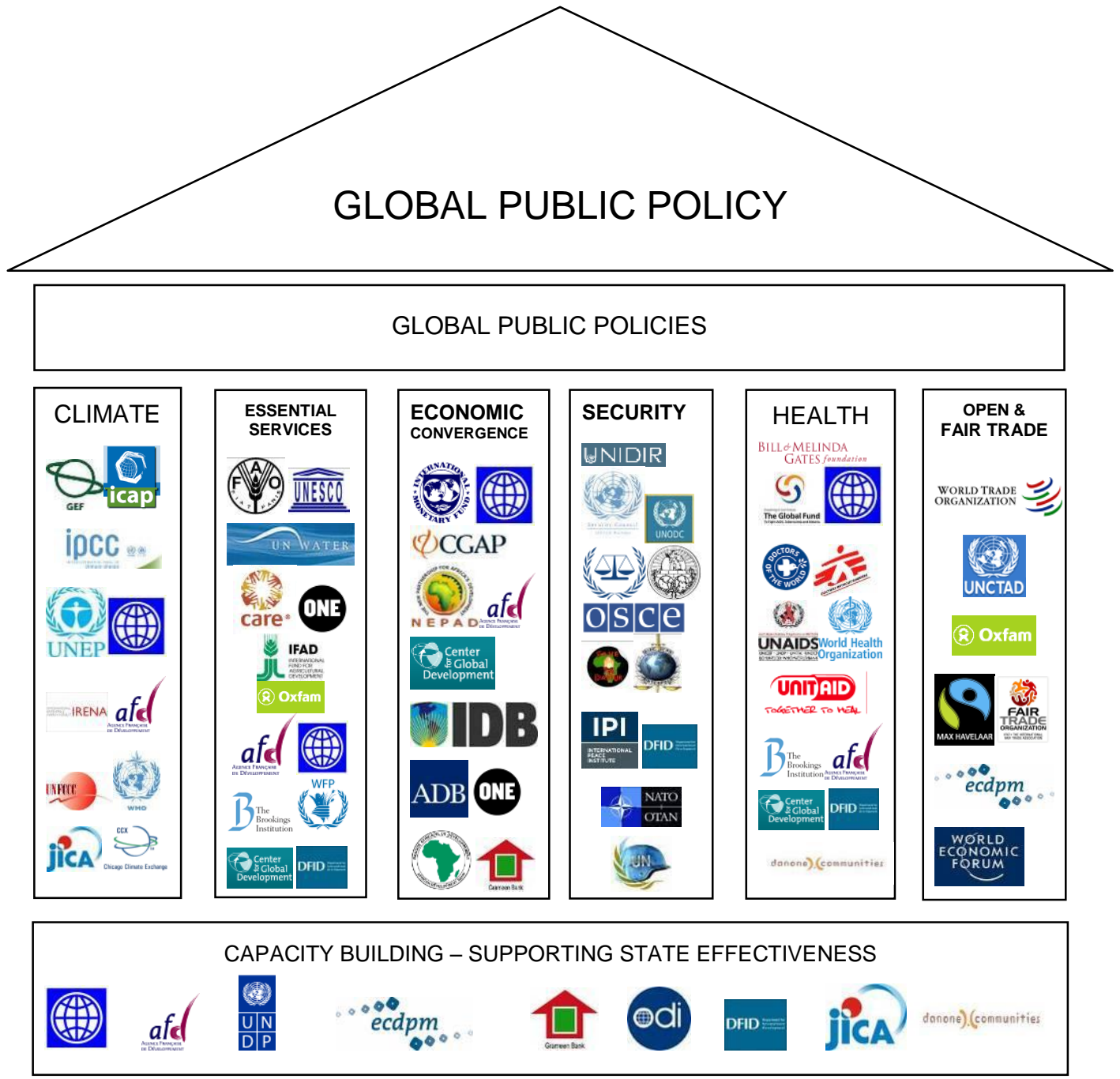

\subsection{An institutional jungle}

For most of its history, international development assistance was channelled from donor states to recipient governments though traditional bilateral aid programs. Part of the resources were pooled between donor countries, and delivered through a few multilateral organizations. But this oligopolistic cooperation model of aid delivery has exploded in recent years, with the intrusion of a whole range of public, private and hybrid actors who each deliver a growing variety of public goods. In these early years of the $21^{\text {st }}$ century the scale of the challenges of international health, security, environmental degradation or poverty is such that making a difference in any of these fields implies bringing into motion a constellation of actors. 
Figure 1, Members of the GAVI Alliance

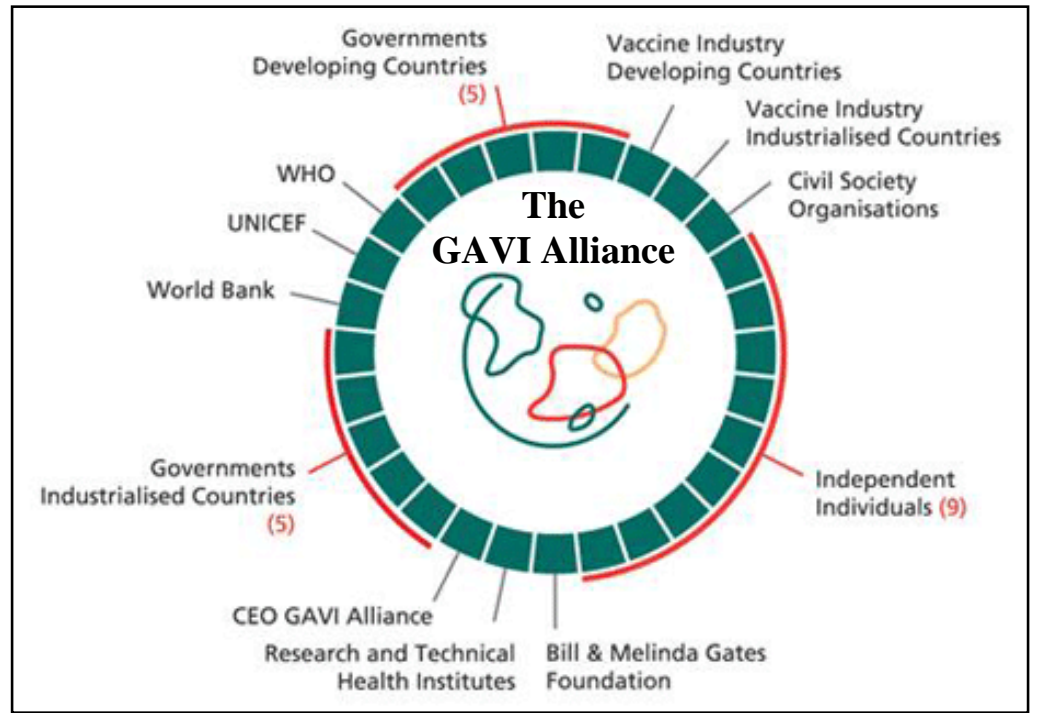

In the nascent world of global public policies, no single policy goal can be pursued effectively without bringing tens of players around the table. Take international health, long characterised by the predominance of a single multilateral institution - the World Health Organisation and a few international donors. Today, the global effort to prevent or treat pandemics such as HIV/AIDS or malaria involves a series of multilateral organisations (the WHO, but also the World Bank, UNITAID, UNICEF, regional actors such as the African Development Bank and others) and their offshoots (multi-donor funds such as the Global Fund to Fight AIDS, Tuberculosis and Malaria), bilateral actors (sometimes several different organisations and programs per donor country), Non-Governmental Organisations (specialized NGOs such as Act Up, Doctors Without Borders or their counterparts in recipient countries), foundations (the Bill and Melinda Gates foundation has become a key actor in global health over the last decade), think tanks and institutes (such as the Institut Pasteur network), plus a few hybrid institutional animals (such as the GAVI Alliance, a platform of actors involved in the global effort to promote immunization). Although it is perhaps most striking in the domain of health, a sector in which over 100 major organizations are involved ${ }^{8}$, the proliferation of aid actors is also a feature of global efforts for environmental protection, humanitarian relief or education.

Not only do more and more players take part in this policy, but they do so in increasingly different ways. Each of them has its own world vision, body of doctrine and strategy, mobilises resources of various volumes and kinds, disburses them through distinct instruments, is equipped with its own procedures and answers to their own accountability systems. The result is that whether we turn to the protection of biodiversity, the fight against malnutrition or debt relief, an incredible array of discourses and policy preferences coexist at one given time on one given issue. Of course, disagreements on global policies are as old as the policies themselves: there was no such thing as spontaneous order in the days of traditional development aid. But the relative similarity between the state actors around the table made it easier to map out disagreements, negotiate compromises and, eventually, reach common decisions. Today the unprecedented heterogeneity of the field's actors makes it difficult to identify their policy preferences, have them participate in discussion processes and ultimately converge.

And we haven't seen anything yet! The continued growth in aid channels over the last two decades is not showing any sign of abating. On the contrary, within each category of actors, the trend is set towards expansion.

${ }^{8}$ IDA (May 2008), "Aid Architecture: An Overview of the Main Trends in Official Development Assistance Flows". 


\section{The demographic surge of global public finance}

Every year there are more, not fewer, multilateral agencies and programs. In the global struggle against climate change, one of the latest babies of the international community is the International Renewable Energy Agency (IREA), inaugurated in early 2009 by some 77 founding member states. Its mandate is to promote environmental protection through the transition towards renewable energy, in part by accelerating the transfer of 'green technologies' to developing nations. Although the world counts an International Energy Agency (IEA), a United Nations' Environment Program (UNEP), a World Bank, large bilateral development agencies and NGOs, each of which have whole departments specialized in renewable energies, the founders of IREA preferred setting up a brand new organization, endowed with its own funding, headquarters and staff. Promoting renewable energy is a desirable public goal. Yet the smooth insertion of IREA into the dense world of agencies will require intense negotiation, thorough strategic thinking and... important coordination costs. While dozens of such multilateral agencies have been created over the last decades, few have disappeared thus far: according to the OECD there are now 263 multilateral organizations active in development, i.e. more than the world's 190-odd countries, and four to five times the number of developing countries they are meant to assist. 25 of them were created between 2000 and $2005^{9}$.

Multi-donor funds have also skyrocketed in recent years. A recent fashion in the international community has been to create new sector-specific (or 'vertical') funds to channel aid towards specific international public goods, particularly health, environment or education. By the end of 2008 , the World Bank alone held a total of $\$ 26.31$ billion in 1,020 active funds, supported by 224 sovereign and non-sovereign donor agencies ${ }^{10}$. Some of these entities, such as the Global Environment Facility (GEF), are endowed with their own council, assembly, secretariat and CEO, which makes these hybrid institutional animals look a lot like multilateral organizations. As this paper is being drafted, the post-Copenhagen climate negotiations promise us a new climate fund, which will need to be coordinated with the multitude of development programs already tackling climate challenges.

A series of new bilateral donors (sometimes called 'emerging donors') have also joined the club in recent years, with their share of resources, development philosophies and agendas. While bilateral development aid in the 1960's essentially came from the United States, France and the United Kingdom, there are now close to 60 bilateral donors financing global policies today. Countries such as China, Mexico, Thailand or Romania, some of which receive World Bank loans, also manage their own bilateral cooperation development programs. Although there are very few reliable statistics available on non-DAC ${ }^{11}$ aid, these new donors are estimated to channel two ${ }^{12}$ to eight ${ }^{13}$ billion dollars of ODA-equivalent to developing nations - a fast-growing chunk of international development finance.

\footnotetext{
${ }^{9}$ KHARAS, H. (2007), "Trends and issues in development aid", Wolfenson Center for Development Working Paper, (1), 15. and KHARAS, H. (2009), "Action on Aid, Steps Towards Making Aid More Effective", Wolfenson Center for Development, 4.

${ }^{10}$ Partnership and Trust Fund Annual Report, 2008.

${ }^{11}$ DAC is the OECD's Development Aid Committee

${ }^{12}$ MANNING, R. (2006): “Will'Emerging Donors' Change the Face of International Co-Operation?”, Development Policy Review, 24(4), 371-385.

${ }^{13}$ KHARAS, H. (2008), "The New Reality of Aid", in Global Development 2.0, Brainard and Chellet, eds., Washington (Brookings).
} 
Traditional donors' bilateral actions are themselves often scattered between ministries, agencies and vertical programs. This is typically the case in the United States, where more than 26 governmental agencies contribute to the country's international development effort, among which five can be said to play a major role. A single developing country in one single year can therefore receive grants for its infrastructures from the Millennium Challenge Account (MCA), funds for HIV treatment from USAID though PEPFAR, emergency relief aid from the Department of Defence and benefit from the US Treasury's debt relief program.

As if this impressive demographic vitality of multilateral and bilateral actors did not suffice to cloud the scene of global policies, subnational entities have initiated their own bilateral projects: networks of local government institutions in developed and developing countries are flourishing around the globe. These decentralized cooperation programs link a city or administrative region in a country of the North and its equivalent in a developing nation, and engage in projects in water and sanitation, education, environment or health. Close to 3,800 French local authorities (regions, departments, cities and city groupings) declare being engaged in decentralized cooperation programs. It is estimated that they channel over 100 million euros of financial resources towards some 8,000 projects in 132 countries $^{14}$.

Putting these different components of bilateral and multilateral aid together, it is no surprise that the number of donors operating per recipient country has skyrocketed in recent years. Efficient contraception is yet to be found to check public development finance's impressive demographic vitality: it is estimated that the average number of bilateral or multilateral donors per recipient country (decentralized cooperation and vertical funds aside) has risen from 3 in 1960 to 30 in $2006^{15}$.

\section{Privatizing international cooperation... with public support}

These numbers, however, do not include the myriad of private actors of international solidarity some of whom finance operations that dwarf those of public organisations. Indeed, the end of state monopoly in development assistance has sparked a boom in private giving, actively encouraged by the governments of advanced economies through generous tax breaks.

A whole range of left-wing, conservative, secular, faith-based, small, medium-size or large NonGovernmental Organisations (NGOs) have mushroomed in all industrialized countries, and have come to represent a considerable proportion of North-South financial transfers. They now deliver about a third of the international programmable assistance. In the United States, private philanthropy has already well surpassed official development aid ${ }^{16}$. Most international development NGOs have field networks that no bilateral or multilateral agency could ever dream of developing - which make them important partners when it comes to linking with aid's final beneficiaries. International activities of NGOs employ more than the staff of bilateral and

\footnotetext{
${ }^{14}$ Figures from the French Minstry of Foreign Affairs: http://cncd.diplomatie.gouv.fr/frontoffice/article.asp?menuid=166\&lv=2\&aid=235

${ }^{15}$ IDA (May 2008), "Aid Architecture: An Overview of the Main Trends in Official Development Assistance Flows".

${ }^{16}$ Figures for 2007 show that the engagement of US private philanthropy with developing countries (an estimated $\$ 36.9$ billion, which comes from adding international efforts of foundations, corporations, private and voluntary organizations, universities and colleges and religious organizations) far exceeded those of US Official Development Assistance (\$21.8 billion). The Index of Global Philanthropy an Remittances 2009, The Hudson Institute, 17.
} 
multilateral organisations combined ${ }^{17}$. Over the space of twenty years, the world's international NGOs have become key players in the intricate global public goods industry.

Despite the severe impact of the 2008 financial crisis on their endowments, philanthropic foundations have also considerably stepped up their funding to international cooperation and solidarity activities in recent years. Foundations in the United States are estimated to have transferred a total of $\$ 3.3$ billion to developing countries in 2007 - particularly in the domains of health, environment and education ${ }^{18}$. The Bill \& Melinda Gates Foundation alone contributed $\$ 2.8$ billion to international solidarity in 2008, with activities in more than 100 different countries. Thanks to its massive investment in vaccine research, it has become one of the cardinal players of international health policy, with considerable influence on bilateral and multilateral aid institutions. Since 1994, it has delivered over \$20 billion worth of grants through its global development and international health programs - i.e. four times the GDP of Niger. European and Asian foundations are also increasing their international engagement, encouraged by increasingly generous tax incentives for private giving.

Private businesses have also emerged as a growing component of international solidarity, as the line between for-profit and non-profit actions has thinned with the globalization of business. In parallel to the expansion of traditional philanthropy actions, corporate social and environmental responsibility (CSR) agendas and budgets have surged - providing precious resources and skills to local and global development efforts. Some companies present in countries with deficient public services have for example gone far beyond their legal obligation to provide for the health and safety of their employees by granting access to health treatment to the communities surrounding the factories. Others are shifting their business strategies to provide essential goods and services to the 'bottom of the pyramid'19 - i.e. some of the world's poorest communities. Transnational corporations have become crucial stakeholders of global efforts to fight public ills, as they now serve as vectors and agents of global public policies ${ }^{20}$. The core strategy of some of these players interacts strongly with existing international public policies: when Danone, a major international food corporation, claims that its strategic mission is to "promote health through better nutrition' in developing countries, does it not take part in international collective action?

Private individuals have themselves become important agents of this budding global public policy - muddying the waters a little further. Every year more and more eminent public figures and 'show-biz' celebrities decide to mobilize their renown in favour of the fight against poverty, hunger, civil war or desertification ${ }^{21}$. As public voices of specific endeavours, the Kenyan activist Wangari Maathai or the Irish artists Bono and Bob Geldof have become important stakeholders, with whom public actors must work. These 'stars' of international development are invited to address global conferences and meet heads of state and the CEOs of the largest international banks and organisations. Their ideas count, as they sway public opinion and political leaders - and therefore have considerable impact on the orientation given to the policy.

17 SALAMON, L., and S. SOKOLOWSKI (2004), Global Civil Society: Dimensions of the Nonprofit Sector, Volume Two. Bloomfield, CT: Kumarian Press.

${ }^{18}$ The Index of Global Philanthropy and Remittances 2009, The Hudson Institute.

${ }^{19}$ PRAHALAD, C.K. (2004), The fortune at the bottom of the pyramid: Eradicating poverty through profits, Wharton School Publishing.

20 BEBEAR, PROGLIO, RIBOUD, and SEVERINO (2008, 15 december): "Le secteur privé, un levier du développement à ne pas négliger," Le Figaro.

${ }^{21}$ WEST, D. (2007), 'Angelina, Mia and Bono: Celebrities and International Development', in Development 2.0, op cit. 
And there is more to come! In just a few years, online loans and donations have brought yet a new type of actor onto the aid scene - one which weighs millions of dollars in small change. Kiva, an online microfinance platform, directly connects internet philanthropists throughout the world with micro-entrepreneurs in the South who need funds to start or grow their businesses. As of March 2010, a total of $\$ 124$ million had been committed in 174,000 loans of an average of $\$ 398$ to entrepreneurs from 52 developing countries $^{22}$. Relatively small-scale today, ephilanthropy is growing rapidly as social networks such as Facebook or Second Life spread the concept. For donors this peer-to-peer form of aid provides the advantage of going straight to the recipient, with concrete short-term, visible impacts. If this trend towards the decentralization of aid is to continue, the face of development aid may well change considerably.

Proliferation does not only affect the supply side in the balkanized market for global public action. As governments have lost the monopoly on the receiving end, the demand for international cooperation has itself become extremely heterogeneous. Political liberalisation in many developing countries has led to the emergence of a myriad of civil society organisations, who benefit from a large share of development funds. It is estimated that there are up to 30,000 national NGOs in developing countries ${ }^{23}$. At the same time the decentralization process at work in many countries throughout the world is increasingly turning local authorities into aid recipients.

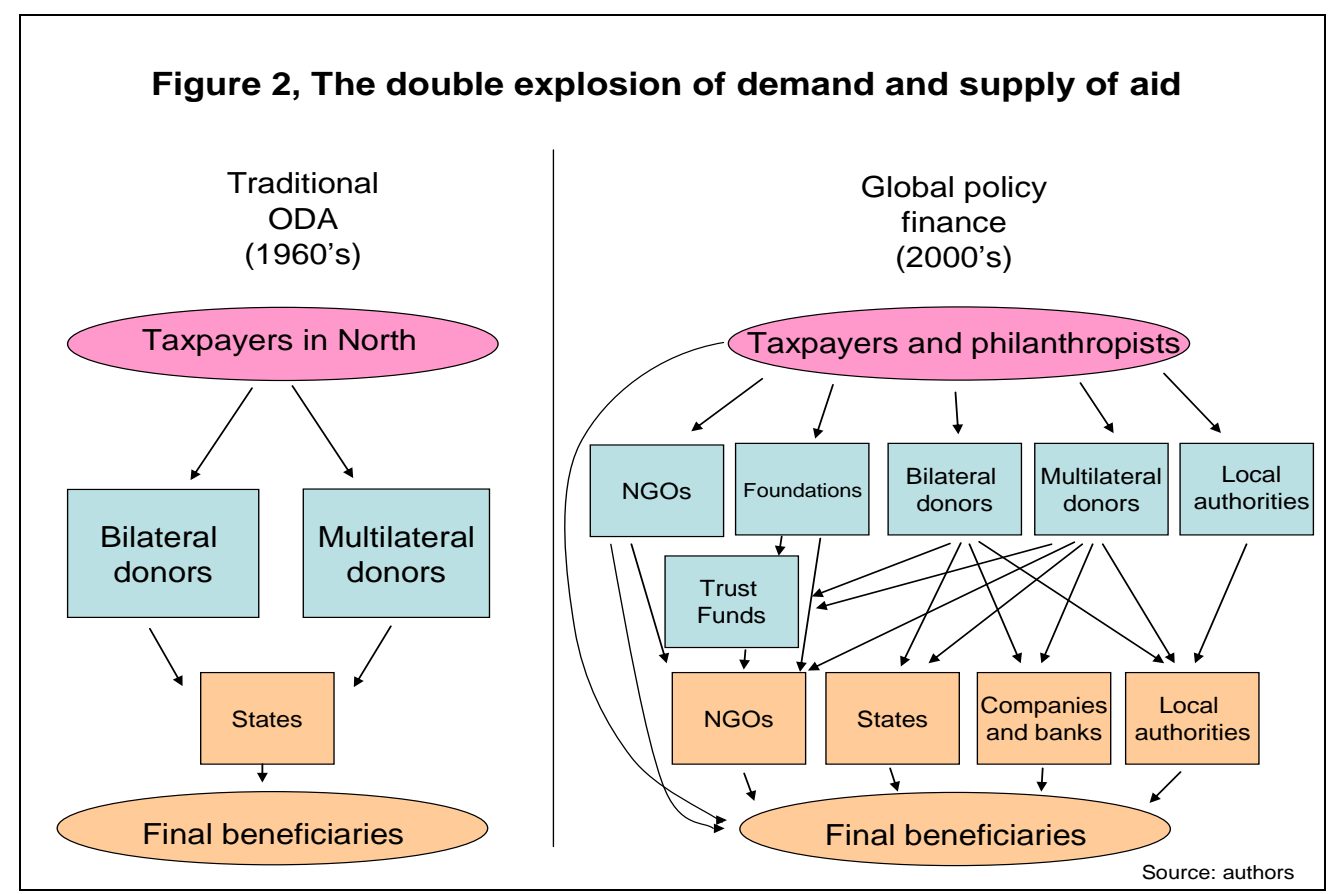

${ }^{22}$ Statistics from www.kiva.org
${ }^{23}$ KHARAS, H. (2007), op cit. 


\section{Hypercollective action: a whole new ball game}

This double trend of proliferation (i.e. the increase in the number of donors) and fragmentation (i.e. the scattering of donor activity) of international cooperation sets the stage for what we have called 'hypercollective action'. Although we will come back to its implications in the following sections, it may be worth to say a few words about this concept at this stage.

We claim that the recent surge in the number of actors involved in the management of global challenges takes the world of international cooperation into a whole new ball game - one in which the rules change as the number of players increases. Indeed, although the first characteristic of hypercollective action is the rapidly increasing number of actors that take part in a given policy, hypercollective action is not just about there being many more actors around the table. These actors of international cooperation are also much more heterogeneous in size, structure, processes and objectives than before. They each have their own form of legitimacy, very different motivations for engaging in the policy, very different understandings of what is meant by 'development', 'security' or 'environmental protection', different assumptions as to how international action can contribute to these policy goals, and different discourses to explain the policy ecosystem they inhabit. These different legitimacies, motivations, understandings, assumptions and discourses coexist, interact, and often oppose one another. In the absence of any legitimate arbitrator, there is no obvious way to articulate these views or to make them converge - which does not facilitate agreement on common objectives or rules of the game.

In this sense hypercollective action is not just more collective action, but very different collective action. This new mode of production of global policies is reshuffling the way international cooperation regimes operate. One of the consequences of this proliferation of actors is that the policy-making process is increasingly decentralised, and that the arenas where action-plans are devised and negotiated are more diverse. Rather than convening decision-makers delegated by their authorities in traditional international negotiations, these new policy negotiation processes increasingly involve the policies' 'stakeholders' - i.e. individuals and institutions who have to be 'on board' for things to evolve. All policy stakeholders contribute in one way or another to policy design and implementation.

To follow the sports metaphor, we are at a phase of international policies where thousands of actors are playing different ball games in the same field - with no referee! 


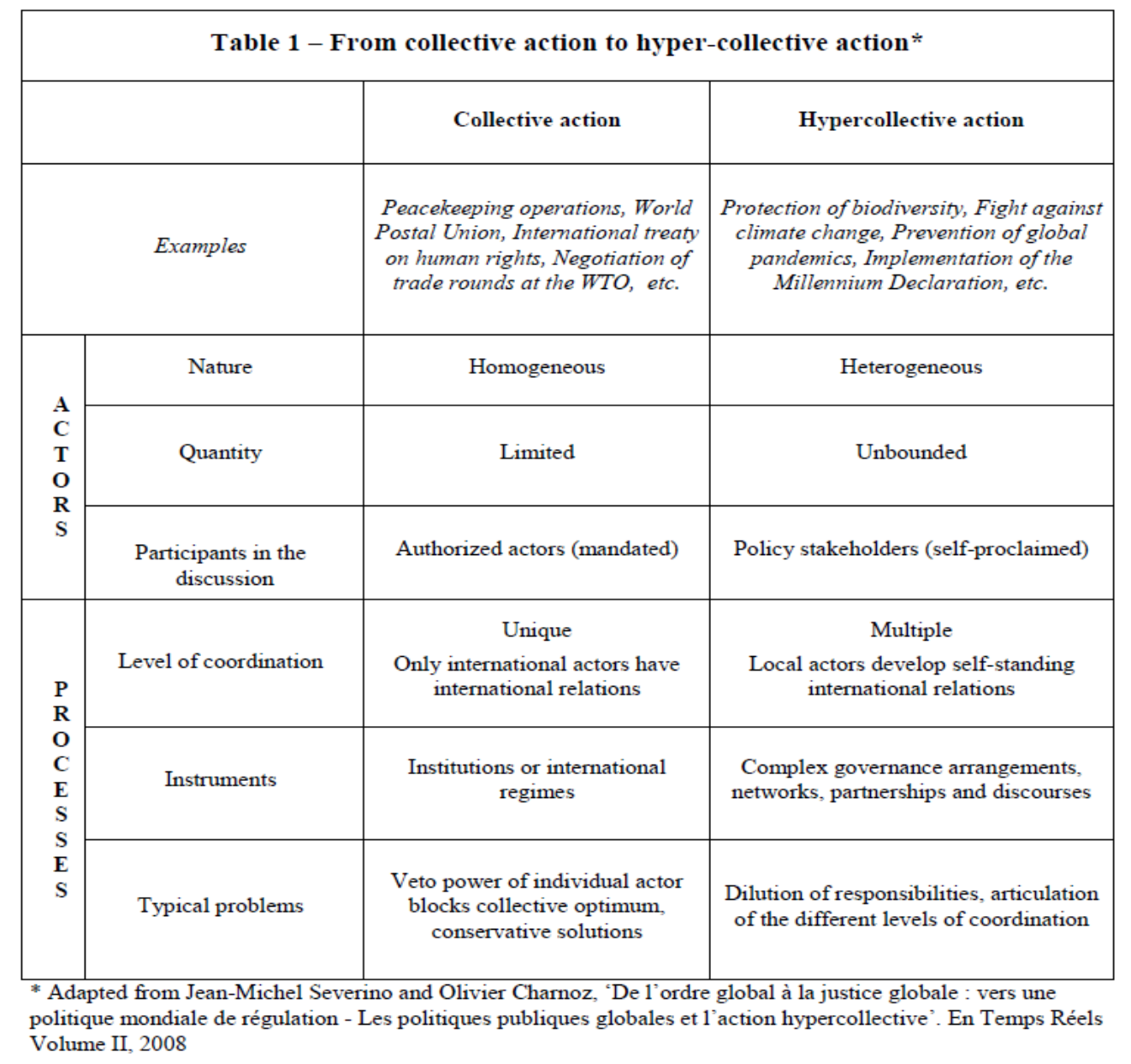

\subsection{Jungle hazards}

Let us be clear: we are not pessimists of hypercollective action. On the contrary, we believe that the surge of actors involved in international cooperation offers global policy financing a welcome breath of fresh air, and that this exciting phase of international cooperation is one where new solutions will be found thanks to the cross-fertilization of very different experiences. Just as the extreme biodiversity of the world's jungles constitutes a wonder of the world, the diversity of this global public policy ecosystem needs to be preserved. Yet all jungles have their hazards, and we too are forced to recognize that the twin movement toward proliferation and fragmentation that characterizes the world of hypercollective action gives an awkward feeling of dizziness.

Indeed, all signs point to the fact that there is no captain aboard the complex vessel of global public policy - on whose shoulders ultimately lies the response to some of humanity's greatest threats. The movement of this composite body of actors, bereft of any overarching authority or comprehensive regulation framework, gives no clear sense of direction. In fact it is more akin to pure Brownian motion, in which the frictions between its multiplying particles produce a Joule effect exponentially linked to their number. The dispersion of international collective action has gone so far in recent years that it carries considerable costs in terms of efficiency, time, coherence and, ultimately, credibility for this emerging global policy. The nature and scale of 
these costs have been amply discussed in the case of international development assistance ${ }^{24}$. Two types of problems emerge as major hindrances to global public policies' effectiveness in the world of hypercollective action: policy mismatch and capacity poaching.

\section{Policy mismatch}

The first instance of 'policy mismatch' stems from the unhealthy competition between actors in the provision of policy advice in those recipient states where affirmed government leadership or inclusive instances for national policy dialogue are lacking. During the first decades of international development history, things were relatively simple: those countries who received funding from the West received economic advice from American, Japanese and European ministries of international cooperation, while those who chose the Socialist camp implemented Maoist or soviet-style reforms. Informed commentators will make the point that this did not make donor strategies particularly efficient in themselves. Unfortunately, this is correct. Yet with the multiplication of donors in both kind and number (each donor coming with his vision of what constitutes a 'good' health or education policy and corresponding funding conditionality), a developing country can now receive not only bad advice, but also its exact opposite (probably as poor) on the way to proceed on any given component of its development program at any given time. In the absence of an overarching donor authority the myriad of actors active in international cooperation feel bound by no common rules, and dispense their own policy advice based on their own agendas.

Another particularly harmful type of policy mismatch caused by the current aid architecture is the lack of fit between donor interventions and local development priorities. This paradox often stems from the excessive concentration of international public support: the increasing earmarking of financial flows to fit donor priorities have led to difficulties in adapting funding to recipient nations' most fundamental needs. A case in point is the global struggle against HIV/AIDS and its encroachment on the funding of national health programs. A study on donor interventions in Rwanda shows that $75 \%$ of donor aid goes directly to NGOs or is managed by donors through their own projects. Because international donors have made HIV/AIDS one of their top global priorities, the bulk of this financing is dedicated to fighting this disease: $\$ 46$ million is earmarked for HIV/AIDS, \$18 million for malaria and only \$1 million for childhood illnesses. This is paradoxical in a country with a comparatively small $3 \%$ HIV/AIDS prevalence rate, but very high infant mortality rates (118 per 1000), where malaria kills more than AIDS but is far cheaper to treat and where the government has made the access to essential health services its top priority ${ }^{25}$. The result is that HIV-positive mothers are given sophisticated retroviral treatments, but still cannot obtain even the most rudimentary of obstetric and gynaecological care or infant immunizations. ${ }^{26}$ As Zambia's minister of health observed, "there is no point giving a child drugs to treat HIV if they then drink infected water and die of cholera"27.

\footnotetext{
${ }^{24}$ See for example European Commission (2009), Aid Effectiveness Agenda : Benefits of a European Approach. A study on the price of fragmentation.

${ }^{25}$ IDA (2008): “Aid Architecture: An Overview of the Main Trends in Official Development Assistance Flows”, p. 17.

${ }^{26}$ GARRETT, L. (2007), “The Challenge of Global Health", Foreign Affairs, 86(1).

${ }^{27}$ Quoted in the Financial Times, From Symptom to System, September 28, 2007.
} 
Figure 3, International funding for HIV/AIDS, Malaria and the Integrated Management of Childhood Diseases (IMCI) in Rwanda (source: IDA 2008)

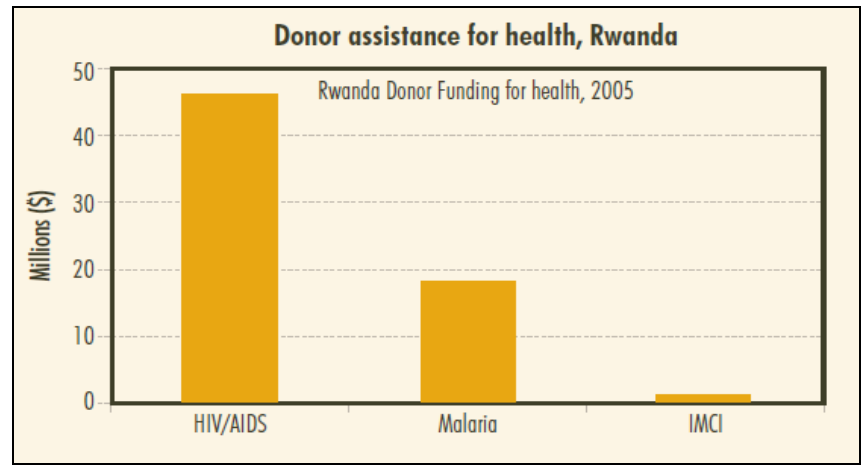

The third policy mismatch that can be traced back to this institutional jungle is the unsatisfactory allocation of international aid across sectors and geographies. In this fragmented and increasingly decentralized policy world, no overarching instance is responsible for ensuring a rational allotment of funds, such that the bulk of aid is channelled to whatever is fashionable for donors to fund and wherever it is trendy to work at a given moment in time. Given the varying ability of lobbies to attract attention to their cause, global efforts toward certain causes or countries are relatively over-financed, while other crucial public policies and regions remain orphans of international aid. This generates duplication, overlap and a waste of precious resources.

The Central African Republic has long been a typical 'aid orphan', stuck in the grey zone between humanitarian and development assistance (figure 4); its population subject to the double penalty of having a weak government and little external support. It is not difficult to conceive that each donor has an inherent interest in investing its funding in those developing countries where it is likely to produce maximum effects and visibility, hoping that the rest of the donor community will take care of the others.

Figure 4, Official aid flows to the Central African Republic (CAR) Source: T.Lanzer, UNDP

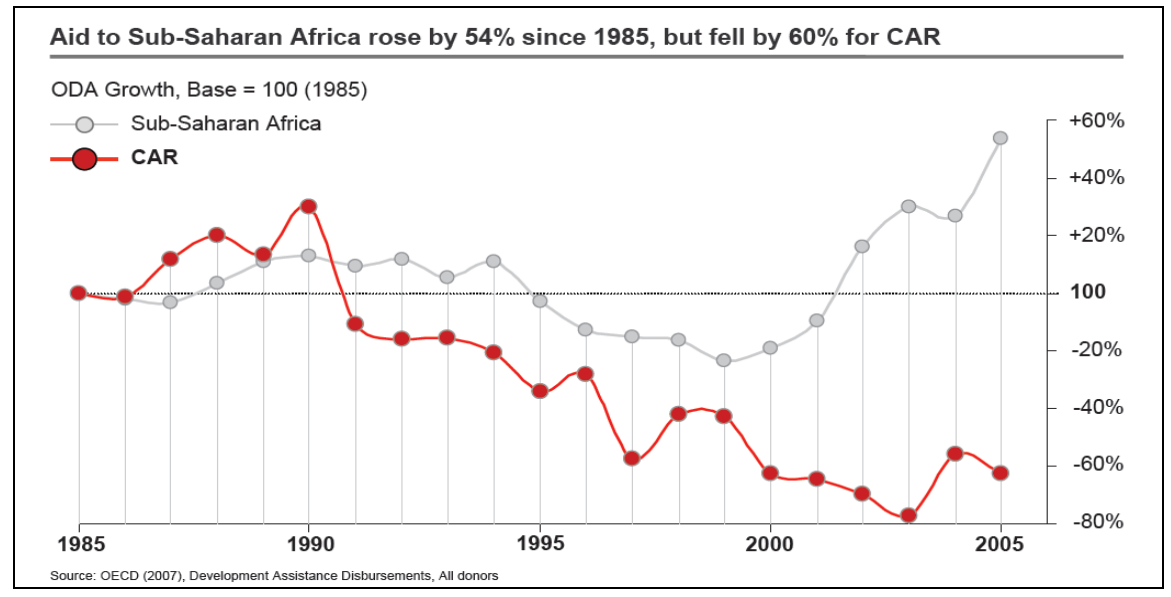

However, this perfectly rational choice of individual donors has very detrimental effects on aid's overall effectiveness, both in aid darling and aid orphan countries. One of the corollaries of this gregarious donor behaviour is the volatility of aid flows. Although one might expect that the fragmentation of aid actors would help reduce the volatility of aid, it appears instead to have 
increased in recent years ${ }^{28}$ - as most development actors respond to similar incentives in deciding to increase or decrease their aid commitments. Recent research suggests that aid shocks faced by low income countries are comparable in size and frequency to major global economic shocks such as the Great Depression or the two World Wars ${ }^{29}$.

In sum, states receiving international support get the worst of recent evolutions in the policy's architecture: excessive fragmentation of policy advice combined with the risk generated by the excessive concentration of financial support.

\section{Capacity poaching}

The second hazard of the institutional jungle which characterises development assistance is also well documented. It is the considerable administrative burden placed by a crowded aid industry on recipient states confronted with weak administrative capacities ${ }^{30}$. A study has shown that thirty-eight developing countries deal with twenty-five or more active bilateral donors and international organizations on their territory - notwithstanding the myriad of actors from the worlds of international NGOs, foundations and decentralized cooperation ${ }^{31}$. Each of these donors requires availability from national and local authorities, as well as the provision of timeconsuming reports to monitor the advancement of projects and the use of funds. This absorbs precious administrative capacity, which cannot be deployed for national development. Such practices do not stand well with the capacity-building refrain chanted in chorus by these same donors.

Knack and Rahman have found that bureaucratic quality erodes more in recipient countries with greater donor fragmentation, i.e. a large number of donors who each work on a small share of the projects. They find that "in their need to show results, donors each act to maximize the performance of their own projects, and shirk on provision of the [...] human and organizational infrastructure essential for the country's overall long-term development." 32 They also emphasize the detrimental effects of donor 'poaching practices' of qualified local staff, which amounts to a form of brain drain: in countries where administrative capacities are scarce, donors' generous payrolls compete with the national private and public sectors for skilled labour. In some countries senior officials work for internationally-funded NGOs in addition to (or in place of) their poorly-paid government position. Others prefer to leave the civil service to work directly for foreign donors, where they can expect to earn ten to fifteen times more ${ }^{33}$.

\footnotetext{
28 KHARAS, H. (2007), "Trends and issues in development aid", Wolfenson Center for Development Working Paper, (1), 20.

${ }^{29}$ KHARAS, H. (2007), op cit.

${ }^{30}$ KNACK, S., and RAHMAN, A. (2004), "Donor Fragmentation and Bureaucratic Quality in Aid Recipients", World Bank Policy Research Working Paper, (3186).

${ }^{31}$ OECD DAC (January 2008), "Development Co-Operation Report 2009".

${ }^{32}$ KNACK, S., and RAHMAN, A. (2004), op cit.

${ }^{33}$ MICHAILOF, S. (December 2009), "The Seven Capital Sins of the Donor Community in Afghanistan", GMF Policy Brief.
} 


\section{Why traditional solutions won't do}

The diagnosis is now clear, and the consensus largely shared among actors of international cooperation that the multiple costs of proliferation and fragmentation call for urgent improvements in the governance of these emerging - and balkanized - global public policies. There is, however, no consensual blueprint on how to proceed to instil some order in this institutional jungle. This section will try to show that coordination solutions tested in the field of development assistance have been met with semi-successes at best because they have not kept to pace with the changing nature of international collective action. As such, they have failed to address some of the root causes of incoherence.

\subsection{The 'suicidal' and 'gosplanist' temptations}

It remains to be determined what principles can structure effective hypercollective action. What we know for sure is that pitfalls abound; let us begin by exploring two ideological dead-ends on the road to better coherence.

\section{Back to the "Old Boys' Club"}

Some who lament the increasing fragmentation of international cooperation would like to go back to the 'good old days' of traditional development aid, when a few bilateral and (even better in most minds!) multilateral institutions monopolized the business of North / South cooperation. This idea is appealing in theory: if the rising number and diversity of actors is responsible for swelling costs, improving coherence and efficiency would call for reducing them in one way or another. But is this really what the international community should strive to achieve?

This question was raised very concretely in the 1990's, in the context of European integration: some argued that it was absurd to have as many aid agencies as member states, and called for the creation of a single European aid agency to deliver Europe's aid effort. However, full integration of European development aid institutions was not the path chosen - on solid grounds. Indeed, although each European bilateral donor delivers 'European' aid, they do not deliver the same kind of support: German, French, Spanish, Danish, Swedish and British aid agencies each bring a specific technical and geographic know-how, which gives much of its added-value to European aid. Integrating these bilateral aid efforts into one gigantic European aid agency would not only have transferred much of the coordination costs to a supersized centralized structure, thereby further constraining European aid disbursement, but it would also have threatened these precious specificities.

The assumption that policy effectiveness will be boosted through an attrition of players also tends to underestimate the sheer difficulty of reducing their number in a world of 'international anarchy ${ }^{34}$. Assuming that better policy coherence would indeed call for fewer actors in the game, how likely is it that any player of the mushrooming field of international cooperation would accept to disappear? As we have seen, the trend we are witnessing today is not one of decline, but on the contrary one of steady increase of bilateral, multilateral and private actors. Among these new players, few would accept institutional hara-kiri on the ground that the field has now become 'overcrowded'- since all deem to have entered the scene of international cooperation for good reasons in the first place. Traditional actors of international cooperation are

\footnotetext{
${ }^{34} \mathrm{We}$ refer here to the absence of any overarching global authority, that John Hobbes pointed to in 1651 in Leviathan - or The Matter, Forme and Power of a Commonwealth Ecclesiasticall and Civil.
} 
certainly not ready to leave their place to newcomers either, as their long experience in delivering technical and financial support gives them a strong sense of legitimacy.

More importantly perhaps, aid recipients themselves would certainly resist efforts to reduce the number of actors present in their country as with each new player of international cooperation comes the hope of additional funding - or at least a new card to play in the vast diplomatic game of global public policies. Thus, however much one thinks it ought to happen, the voluntary retreat of state or non-state actors from given recipient countries on any significant scale is politically unlikely. And, in the absence of an overarching international authority responsible for overseeing the delivery of global public goods and essential services, there are no means to enforce compulsory disengagement. Who would have the legitimacy, let alone the authority, to decide who stays and who leaves? It has proven difficult enough in recent years for a few European bilateral donors to withdraw from certain sectors in a few countries where they clearly did not have a comparative advantage.

Whether we applaud or lament it, the genie will not go back into the bottle. The costs associated with proliferation of both donors and receivers are here to stay, and can be seen as the price to pay for a dynamic and innovative development aid system. While we can certainly work to reduce these costs, they should be factored into realistic appraisals of the future aid architecture $^{35}$. Moreover, as we have seen, diversity is not the problem. Incoherence is. And incoherence is what donor coordination efforts should aim to reduce. Because it is neither possible nor desirable, institutional suicide is not the Holy Grail of aid effectiveness.

\section{Erecting a Leviathan}

Another popular misconception, particularly fashionable in development aid bureaucracies, is that the solution will come from the establishment of a vast aid coordination/harmonisation machinery, composed of regular high-level meetings on donor coordination, permanent headquarter collaboration structures and their equivalents in the field, plus a series of donor 'codes of conduct'. Assuming that the contemporary world of global policies is akin to John Hobbes' international anarchy, Gosplanists see the solution in establishing a coordination Leviathan.

Clearly the costs of ill-coordination amongst donors represent a considerable burden for all actors of the field, and ought to be reduced. Yet it remains to be seen how they fare compared to the costs of a centralized coordination machinery. From year to year, the latter is becoming increasingly burdensome for donor countries and international agencies, who dedicate a good deal of their time, energy and resources to donor meetings - both at the field and headquarter levels. In each development agency, entire departments have been staffed with bright experts to handle the gargantuan task of 'donor coordination'. Rather than searching for optimal strategies to respond to recipient states' needs, a lot of their energy is spent trying to convince their counterparts that their institution's strategy is optimal. At the field level 'donor coordination secretariats' have been set up, dedicated exclusively to this purpose ${ }^{36}$ ! While coordination costs (theoretically borne by donors) could be accepted as a lesser evil in order to reduce incoherence costs (often borne by recipient countries), we must ensure that the former do not overly exceed

\footnotetext{
35 SEVERINO, JM. and CHARNOZ, O. (2008), De l'ordre global à la justice globale: vers une politique mondiale de régulation, vol. 2. En temps réels.

${ }^{36}$ A technical secretariat (STELA) was created by the donors active in Burkina Faso in 2005 to implement the recommendations of the Rome and Paris Declarations.
} 
the savings in terms of the latter ${ }^{37}$. At times it seems that coordination and harmonization efforts are the Sisyphus tasks of donor agencies. Used generously in some circumstances and sparingly in others, they have led to sub-optimal equilibriums. Several years down the path of donor coordination, the time has come to analyse the comparative merits of Gosplan and anarchy - or, to put it in a more appropriate way, to undertake a serious cost-benefit analysis of donor coordination efforts ${ }^{38}$.

A likely finding would be that the slope of the coordination cost curve increases the further collaboration efforts are pushed: the more donors try to attune their approaches, the more difficult it gets - as they move from easy steps of information-sharing to difficult changes to their core strategies ${ }^{39}$. What this means is not that coordination and harmonisation costs ought to be reduced, but that they should be assessed relative to their gains - at a time when demands are rising in recipient nations for rapid responses to urgent problems ${ }^{40}$.

Coordination and harmonization of donor practices are not end in themselves, but should always remain means to deliver more effective aid. More coordination and harmonisation is not always better: there is an optimal level of cooperation and harmonisation, which allows for better coherence while leaving space for a healthy level of diversity and emulation.

Figure 5, A cost-benefit analysis of donor coordination efforts

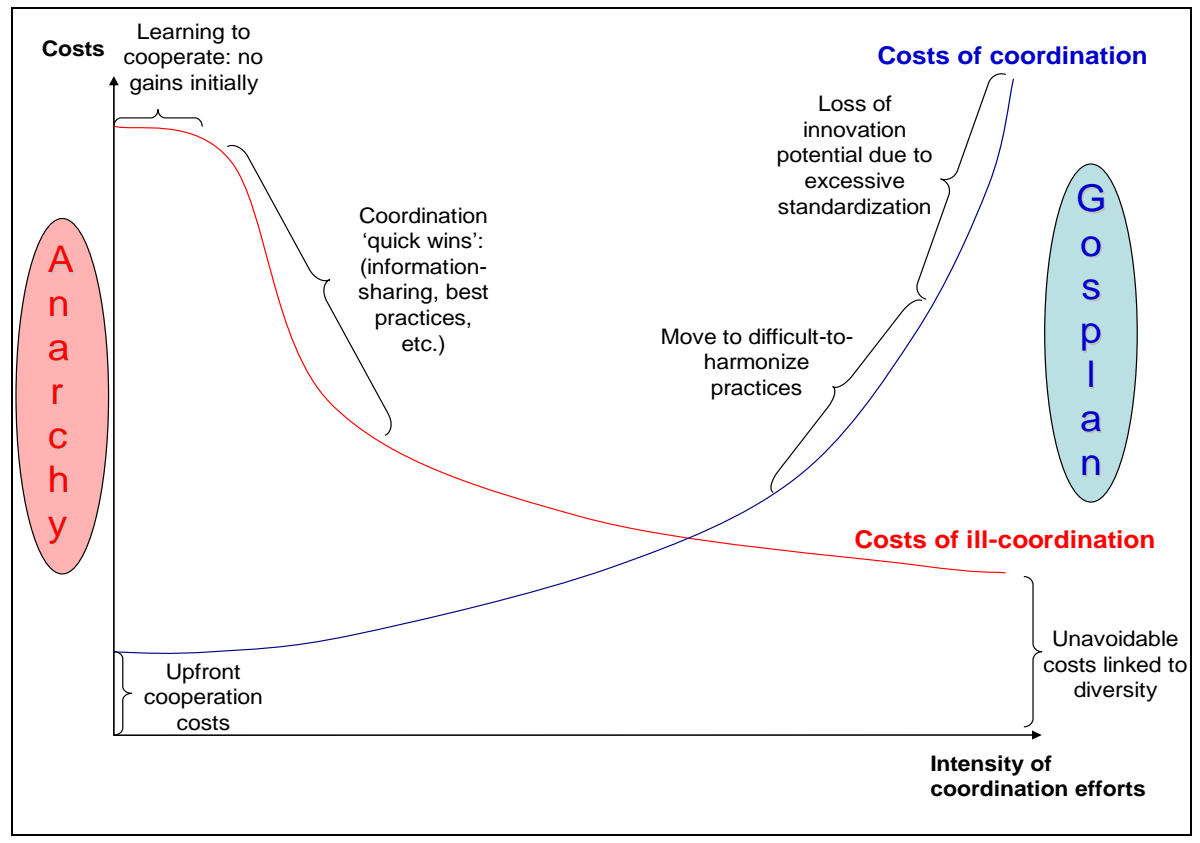

\footnotetext{
${ }^{37}$ Under the - reasonable- hypothesis that donor costs are opportunity costs for development, and that donor savings ultimately benefit recipient nations.

${ }^{38}$ Such a study has been launched by the Agence Française de Développement: "Regards croisés sur l'aide au développement", internal document, AFD 2009.

${ }^{39}$ KHARAS, H., and HERMIAS, J. (February 2008), “Competition, Not Coordination: Making European Foreign Aid More Effective", Development and Cooperation, 49(2).

${ }^{40}$ A case in hand was the seminar organized in 2008 by the President of Senegal on donor effectiveness. It became clear in the course of discussions that, for many aid recipients, donor reactivity and capacity to adapt to needs expressed by the beneficiaries constitutes an important element of aid effectiveness. Traditional donors tied to the rules of the Paris Declaration were estimated not to fare as well as emerging donors such as China or India, who were bound by less red tape and could respond in a few months to funding demands in just about any sector.
} 


\subsection{The Paris Declaration: too much, too little?}

These thoughts lead us to take a closer look at the 'Paris Declaration', which appears as a first attempt to tackle international policy coordination problems in the field of development aid ${ }^{41}$. The framework developed in the Declaration on Aid Effectiveness' five key principles (and the Accra 'Agenda for Action' of September 2008) were meant to orient the donor community's actions and pave the way for greater efficiency. What can we learn from this attempt to improve international policy coherence? Can the principles on which the Paris Declaration is based serve as a model to organise effective hypercollective action and structure emerging global public policies?

\section{A (very) rough draft}

The Paris Declaration process provides a consensual statement of the problem, and affirms the necessity for the donor community to march towards common goals. As such, it represents a crucial landmark on the path towards coherence. At the Third High Level Forum on Aid Effectiveness in Accra, discussions on aid coordination were led jointly by representatives of both donor and recipient countries, which marked the beginnings of a North/South approach to the governance of aid. Yet, outside the walls of conference halls (within which the five principles of 'ownership', 'alignment', 'harmonization', 'managing for results' and 'mutual accountability' resonate as would a profession of faith), there is a rising sense of unease within the development community with the way this 'donor consensus' is being played out in practice ${ }^{42}$. According to a growing number of critics, the Paris Declaration process suffers from a number of weaknesses that make this laudable attempt at international coordination a weak foundation on which to build the kind of hypercollective action that is needed to manage emerging global public policies.

The main reason for this is that it has failed to take into account the revolution that has affected development aid's objectives, actors and instruments - as if the Paris Declaration has set itself to regulate an activity (the delivery of traditional 'Official Development Assistance') that has already ceased to exist as $\operatorname{such}^{43}$. Indeed, many say that the Paris Declaration has missed the wave of instrumental innovations that has challenged development aid practices over the last decade $^{44}$. Its coordination efforts focus on the narrow perimeter of grants and technical assistance - to the detriment of the vast array of instruments that have been developed in recent years to assist national or local development strategies. As a result, a binary aid landscape is under construction in many recipient countries: an inter-donor framework to manage grants and sovereign lending, neatly structured according to the principles of the Paris Declaration, coexists with a proliferating field of 'other' development methods and initiatives. A donor with only $10 \%$ of its portfolio worth of grants and ODA-eligible loans will therefore be concerned with the Paris Declaration coordination agenda for only $10 \%$ of its activity! Its non-concessional loan, guarantee or equity investment projects fall outside the bounds of the Declaration - although

\footnotetext{
${ }^{41}$ Ian Goldin and Tiffany Vogel embark on a similar exercise with respect to the governance of financial commons. They, too, find that existing institutions are inadequate to protect the international community against $21^{\text {st }}$ century systemic risks. Goldin, GOLDIN, I., and VOGEL, T. (2010), "Global Governance and Systemic Risk in the 21st Century: Lessons from the Financial Crisis", Global Policy, 1(1).

${ }^{42}$ See BIRDSALL, N., and K. VYBORNY (August 2008), “A Little Less Talk: Six Steps to Get Some Action from the Accra Agenda", Center for Global Development Notes.

${ }^{43}$ SEVERINO, JM., RAY, O., 2009, op cit.

${ }^{44}$ For a description of this instrumental revolution, please refer to SEVERINO, JM. and RAY, O., (March 2009), "The End of ODA - Death and Rebirth of a Global Public Policy", Center for Global Development Working Papers.
} 
they may well concern the exact same sectors. In this uncharted territory institutional anarchy still rules, and the donor is free to proceed at its discretion in terms of strategy and procedure.

The Paris Declaration process is also structured as if the explosion in the number and kind of actors involved in development aid hadn't happened, both on the donor and recipient sides. As an OECD project, the Paris Declaration did not include the new bilateral donors or the non-state organisations involved in the policy - and thus left aside the most dynamic part of international aid flows. Of course, civil society organisations are represented at most donor conferences; the Accra High-Level Forum on Aid Effectiveness was an important step in giving them a greater role in terms of policy input. However there is to this day no central framework to coordinate public and private aid flows to a given country or sector, such that each bilateral donor engages in its own bilateral outreach initiatives to foundations, NGOs, think tanks and emerging donors. Naturally, part of the inherent difficulty of dealing with the proliferation of aid channels is that diverse actors cannot be managed in the same way. However, excluding the bulk of them from coordination efforts on the grounds that they are different seems a little radical, and risks exacerbating the duality of the aid landscape ${ }^{45}$.

More fundamentally perhaps, evaluations show that the Paris Declaration process gives players in the system few motivations to play the coordination game genuinely - which may explain why considerable donor incoherence persists despite repeated statements of good intentions from all parties $^{46}$. The current incentive mix leads many actors to adopt the coordination lingo, but to make their practices evolve only marginally in practice. Too little notice has been paid to the incitements that would be needed for the different actors to implement them. Frameworks for hypercollective action will need to address the political economy of cooperation ${ }^{47}$. We will come back to this crucial point in the third part of the paper.

\section{Supply or demand-driven aid?}

While the Paris Declaration starts from a good analysis of the difficulties that affect aid's supplyside (i.e. the donor community), many critics highlight that it fails to recognize the extreme diversity of the demand for aid. It relies on a set of implicit assumptions on the needs and capacity of aid recipient states. The ideal-typical 'recipient state' is poor, very dependent on international aid, and it has sufficient administrative capacity to carry out projects and define credible national policies. A more subtle appraisal of the heterogeneity of demand would reveal that coordination processes of the Paris declaration are very useful under a specific set of circumstances - but which only account for a small share of country situations.

Consider the recommendation to align donor procedures, development policies and funding priorities to those of partner countries: this makes a lot of sense in theory, as we cannot expect recipient countries to pay the price of procedural cacophony, instrumental proliferation and

\footnotetext{
${ }^{45}$ The absence of such a formal platform for cooperation among all actors of development aid is all the more striking as other policies have equipped themselves with such open policy-making structures. This is for example the case of the field of humanitarian aid, whose 'Global Humanitarian Platform' gathers UN organisations, NGOs, the Red Cross and Red Crescent networks.

${ }^{46}$ A series of surveys monitoring the implementation of the Paris Declaration have taken place. All are accessible on the OECD DAC's website. In preparation for the 2008 Accra meeting on Aid Effectiveness, other initiatives were carried out, including Bernard Wood et. Al., 'Evaluation of the Implementation of the Paris Declaration”, July 2008. These various exercise all point to the slow implementation of the commitments and targets agreed on in Paris in 2005.

${ }^{47}$ BARDER, O. (October 2009): "Beyond Planning: Markets and Networks for Better Aid," Center for Global Development Working Papers, (185).
} 
strategic incoherence among donors. But the developing world covers the whole spectrum of institutional capacities.

On the 'weak capacity' end of the spectrum this principle is very theoretical: calls for tenders and anti-money laundering procedures are either lacking or not to be trusted, policies are poorly devised, and government priorities more often reflect those of a political elite than those of the population. A real difficulty of delivering aid in these cases lies in the inbuilt disequilibrium between supply and demand: the (at times) irrational behaviour of 'customers' calls for exerting some form of tutelage on 'demand'. The way this plays out in practice is that donors set the national procedures, policies and priorities on which their strategies are then aligned: in some countries, the government's Poverty Reduction Strategy Paper is even written by World Bank or UNDP staff from start to finish. Is this breach of the principle of alignment necessarily bad? No: at times the donor community is right to impose its conditions. However, pretending in these circumstances that donors align themselves on the government's strategy and are 'accountable' to the government sheds legitimate doubts on the principle of alignment, ownership and mutual accountability, and on the true objectives of donor coordination.

While alignment on national policies and procedure makes little sense in those states that do not have sufficient capacity to express or define their needs, donor harmonization, on the other hand, is crucial. Post-conflict states are a typical case - one in which donors have paradoxically tended to rush to in a precipitated and disorganised fashion. For Afghanistan, the Central African Republic or Haiti, uncoordinated aid can indeed do a lot of harm: not only does competition between donors risk confusing or overwhelming government institutions that are under considerable strain, but donor dispersion may also be used by certain authorities to finance inadequate policies. In these cases foreign donors are right to aim at offering a coherent strategy through upstream donor coordination. Clearly, in some countries the disequilibrium between supply and demand is such that the "market for aid" ${ }^{48}$ left to itself cannot be efficient: donor harmonization is the least harmful way to provide effective aid. Rather than alignment on inadequate demand, the top priority ought to be building the capacity to define coherent policy needs on the part of government authorities.

Towards the other pole of the state capacity continuum, things look very different. In a growing number of countries eligible to development assistance, demand for aid is highly organized and structured. The national and local authorities are able to elaborate a sophisticated demand based on the needs of their economies. They perceive development aid as a resource among others (FDI, market loans and bond emissions) to finance their public policy priorities. In these countries competition between donors is not a concern, quite the contrary: authorities find that it spurs innovation and, more importantly perhaps, forces donors to align their action to government priorities. The authorities are able to choose the level of coordination they deem most efficient, and organize it themselves: in Vietnam, India, Brazil, Tunisia, Turkey, Morocco or China, government authorities did not wait for the Paris Declaration to ensure the coordination of aid. Because their bureaucracies do not lack competent staff, they prefer to cope with donor coordination costs - as this allows considerable gains in terms of ownership.

These states are in no need of an integrated offer; in fact most of them resent any form of upstream donor cooperation that would cause them to face a cartel of donors. Government authorities provide carrots and sticks for donors - who better keep to the government's strategies

48 EASTERLY, W. (2002), 'The Carlet of Good Intentions : Bureaucracy vs. Markets in Foreign Aid', Center for Global Development Working Paper No.4. And KLEIN M. and HARFORD T. (2005) The Market for Aid, The International Finance Corporation, Washington DC. 
if they want to continue working in the country. These states are in a very different power relationship toward the aid community, as they can afford to refuse funding when it does not fit national priorities, or to kick out an unruly donor. This is what Brazil made clear when it decided to launch a rainforest protection fund: the Strategic Affairs Minister Roberto Mangabeira Unger warned that the $\$ 21$ billion environmental fund will be a way for foreign governments to support Brazil's initiatives "without exerting any influence over our national policy", making it crystal clear that "we are not going to trade sovereignty for money" 49 . The authorities of such partner countries are at best ambivalent about the Paris Declaration. They are used to ordering 'à la carte' among donor projects, advice and policy options. Harmonisation efforts sound like an attempt by donors to move to a set menu.

Somewhere in between these two poles of the capacity continuum are countries where the Paris Declaration principles are well adapted, and their implementation brings satisfaction to both government authorities and DAC donors. This is typically the case in Mozambique, Ghana or Burkina Faso: although the coordination process needed to reach common strategy is often timeconsuming, the increasing recourse to budget support has brought considerable improvements in terms of capacity, government ownership and coherence.

What should we take away from this dissection of the demand for aid? The problem is not so much the principles of the Paris Declaration than their uniform application to the whole range of beneficiaries. According to the capacity-building discourse of aid agencies, international assistance ought to aim to move recipient countries from the 'weak governance' pole of the continuum to the 'strong capacity' end - which implies progressively leaving the coordination of donor activity to the receiving state. In a way, the Paris Declaration donor coordination processes should aim at their own extinction as countries move up the scale of capacities and donor coordination. Is the aid community ready to accept this vision of alignment? The lack of interest of the donor community to fund Brazil's rainforest protection fund suggests that true alignment remains rare in practice.

${ }^{49}$ www.upi.com 'Brazil starts rain forest protection fund', 2 August 2008. 


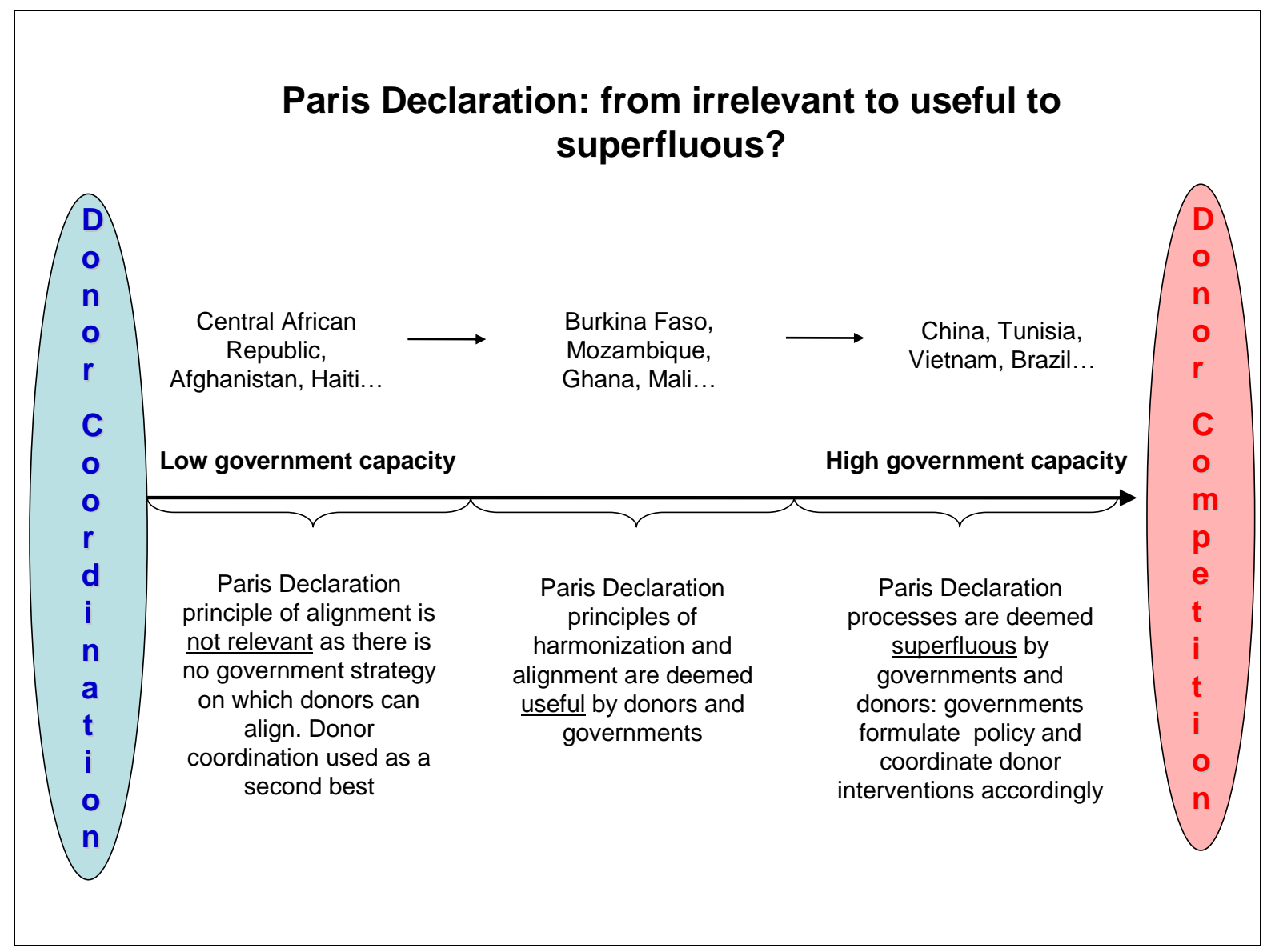

\section{The double trap}

Finally, the Paris declaration seems to be caught in two policy traps.

The first is the 'participation' trap. As coordination groups have proliferated on any local policy issue, from gender to power generation, the process has degenerated into a discussion nightmare in many countries, where small donors may freeze policy-making for years. In most countries, a few donors represent the bulk of development assistance. In Ethiopia, four donors ${ }^{50}$ provide over $60 \%$ of the financial support to the country. Yet, consulting the ultimate donor (who provides less than $1 \%$ of overall aid) may monopolize the attention of the government or entire donor community if this donor has chosen to play the obstruction game. In this case the laudable objective of giving all actors a voice is counterproductive.

The second trap lies consists in placing the onus of improvement in aid delivery on actors that do not have all the cards in their hands: the bulk of coordination efforts take place at the field level, while most field actors have in effect little capacity to adapt disbursement policies and regulations. Indeed, the latter are often decided upon at the central level by boards and parliaments who are unaware of local realities and primarily concerned by safeguard and reporting policies. Rushing to the field is developers' Eve's temptation; it has naturally been the Paris Declaration's. But when it comes to improving the coherence of global policies, a good dose of heavy lifting has to be done at the central level. It is with the fight against poverty,

\footnotetext{
${ }^{50}$ The United States, the European Union, the World Bank and the United Kingdom.
} 
climate change or global pandemics as in all battles: combat on the front lines can only be efficient if headquarters do not hamstring the infantry with untenable rules of engagement. Convergence and efficiency have to be addressed at all decision-making levels.

Excessively participatory, the Paris Declaration process is also stuck at the local level, such that it can deliver only with great difficulty the efficiency improvements it promised.

\subsection{De rerum cognescere causas ${ }^{51}$}

How can so much work and goodwill on improving aid effectiveness through coordination lead to such disappointing results? Let us venture a hypothesis: while the Paris Declaration starts from a convincing diagnosis of the problems, success is out of reach because its incantations for donors to do more and better miss some of the root causes of incoherence. Rather than accusing actors of bad will, more attention should be given to the political economy of our emerging global public policies in the context of hypercollective action.

Three syndromes and a paradox appear as in particular need of attention.

\section{The marginal player syndrome}

We call the first perverse incentive the 'marginal player syndrome' - a pure product of the recent explosion in stakeholders of international cooperation. It refers to the situation where donors feel less and less responsible for the success or failure of the projects and programs to which they contribute - due to the fragmentation of aid supply.

Given that the overall cash transfers to the field have not significantly increased over the years, the mushrooming of development actors has implied that the average size of projects or operations financed has decreased sharply - especially with the eruption of NGOs and decentralized cooperation. In 2006 the OECD reported over 81,000 active aid projects worldwide (up from 17,000 in 1996!), the median size of each activity representing only $\$ 67,000$. In this market where most players are marginal, no single actor feels accountable for the final results. The consequence is that all players who consider that they only bring a small stone to the vast development edifice do not feel concerned by coordination efforts. Why would they bother joining costly harmonisation processes? This perverse incentive brought by hypercollective action is not addressed by the Paris Declaration. On the contrary, as donors increase their contributions into common financing pools and reduce the number of projects over which they have direct responsibility, their stakes in success are further diluted.

\footnotetext{
${ }^{51}$ Latin, To know the causes of things
} 
Figure 7, Number of donors per recipient country. (Source : IDA 2008, p. 15)

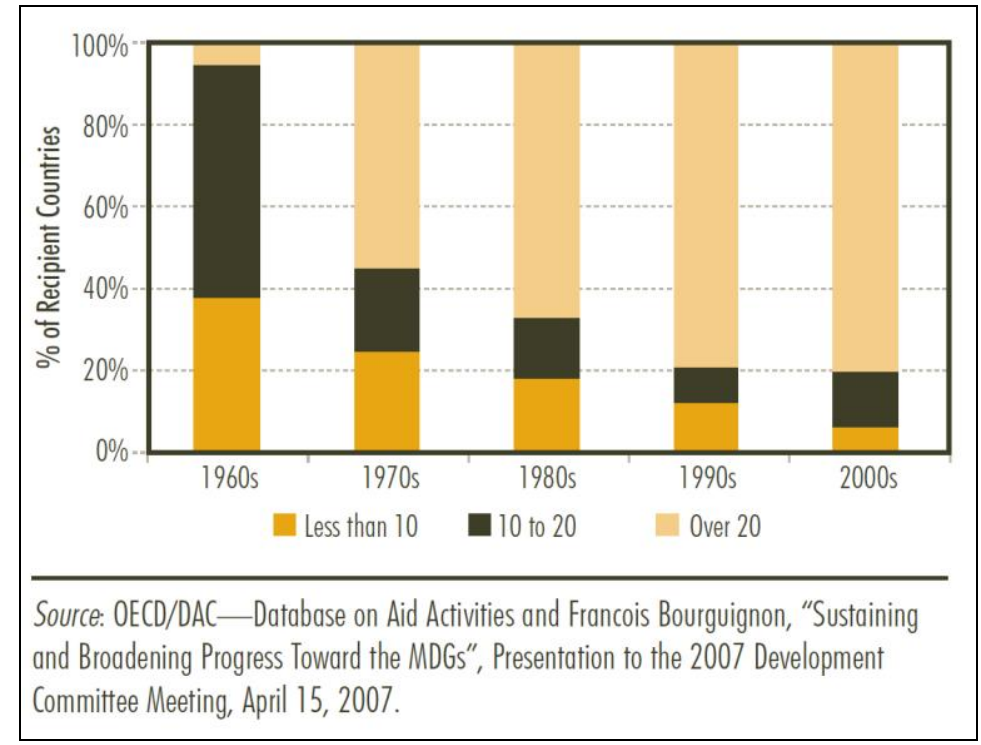

\section{The diverging accountabilities syndrome}

The second lies in the coexistence of at least three systems of accountability in international cooperation policies, from which we cannot expect spontaneous convergence.

Who do development institutions work for? To whom should they be accountable? According to whose needs and objectives should aid's effectiveness be assessed? One answer is that donors work to assist partner governments in their national development strategies, and should therefore aim to respond to their demands (this is what the Paris Declaration principle of 'alignment' is all about). Another possible view is that development ultimately aims to improve the lives of final beneficiaries, and that our actions should therefore stick as closely as possible to their needs. A third understanding of 'accountability' is that taxpayers of donor countries are important stakeholders of this policy, and have a legitimate say in the way their resources are used. Development institutions must therefore be accountable to citizens of donor countries and their elected representatives, and attentive to their priorities.

The coexistence of these three systems of accountability is not a problem in itself, as long as all three of these legitimate constituencies of aid express similar needs and priorities and therefore expect similar actions from development agencies. In an ideal world, governments of recipient countries would voice the most pressing needs expressed by their populations, and donor institutions would be mandated by their constituencies to help them respond to these demands. In reality though, spontaneous convergence is rare. When these three preference functions diverge, accountability towards aid's final beneficiaries rarely gets the upper hand.

The current aid system takes the concept of 'aid effectiveness' for granted, as if aid's effectiveness should be assessed according to one single easily identifiable set of objectives - the welfare of final recipients. Experience shows that the objective function of a bilateral or multilateral actor is in fact much more strongly correlated to the satisfaction of taxpayers, lobbies, institutional shareholders and other vested interests in the North who, although most often professional and concerned, are often very remote from the real needs of final beneficiaries. 
Aid attribution is an example of the way this market failure can affect aid effectiveness: among the important functions of bilateral aid for donor countries is the 'planting of the flag' - i.e. ensuring visibility for the donor country or its various ministers. This issue of visibility and attribution sometimes overrides important development concerns in the allocation of resources. It is no use deploring it, or accusing these preference functions of being illegitimate: they have their own logic and are not, in themselves, incompatible with aid's effectiveness. The real question is how to ensure maximum convergence of the three preference functions, i.e. how to introduce final beneficiaries' preference functions into the political economy of aid. When a foreign minister visits a partner country, it is difficult for him to assess the quality of the aid delivered on the basis of national progress in health, socio-economic welfare or education. He will ask to visit a new clinic, factory or school funded by his country's development assistance, and he will want to communicate the amount of aid committed by his development agency in the country and its rate of disbursement. Few aid actors would agree that maximising project visibility and development expenditures ought to be their key objective. Yet, in the absence of credible indicators of aid impact, development agencies are assessed according to an extremely weak proxy: their capacity to generate visible projects and disburse high volumes of funding quickly.

This perverse incentive to spend the greatest possible amount of taxpayer money in the most visible way is matched by a second one, which also stems from the inadequacy of development indicators. Because donor efforts towards international solidarity are measured in terms of 'Official Development Assistance', bilateral development agencies are too often assessed according to their capacity to 'generate ODA'... rather than addressing partner countries' priority needs. As a result, a state with important problems of criminality will have the greatest difficulty finding funds to build a much-needed prison - as the funding of penitentiaries cannot count as development assistance according to DAC rules. We have discussed at length the weaknesses of the ODA figure. Suffice to say that despite important progress over the last few years, the paucity of measures of impact represents a major blind spot of global public policies.

\section{The evaluation gap syndrome}

The third market failure, which is alone responsible for a considerable chunk of aid incoherence, is the persisting evaluation gap ${ }^{52}$.

Development professionals often complain about the seemingly irrational decisions taken by their political masters. Admittedly, these political decisions are responsible for many of the pendulum swings that are so detrimental to policy, and many of the white elephants that populate the landscape of international development aid. But can decision-makers really be blamed for these inconsiderate choices? Political authorities in donor countries cannot make rational arbitrations on which strategies to favour or where to allocate development aid if they cannot base their decisions on authoritative research regarding what works and what doesn't, and what type of projects should be funded. There is today no existing mechanism that would give an assembly of decision-makers a synthetic and reliable vision of strategic options from which to choose. The resulting practice is that institutions, lobbies and think tanks with varying levels of influence, legitimacy and professionalism offer their opinions on what development strategies ought to be followed and what sectors are currently underfinanced by international aid. Only

\footnotetext{
${ }^{52}$ SAVEDOFF, W., R. LEVINE, N. BIRDSALL, et al. (May 2006), "When will we ever learn? Improving lives through impact evaluation", Report of the Evaluation Gap Working Group. Washington: Center for Global Development.
} 
when the bulk of these voices agree that something has gone wrong is the course corrected, such that precious time and resources are wasted.

The 2007/2008 global food crisis exemplified this dysfunction of the aid industry. Aid to agriculture plummeted in the 1980's and 1990's, as bilateral and multilateral donors alike shifted their attention and aid budgets away from agricultural development to focus on debt relief and the social sectors. The global volume of assistance to agriculture fell from US\$ 6.2 billion to US\$ 2.3 billion between 1980 and $2002^{53}$ (Figure 8 shows this evolution for Sub-Saharan Africa). Since global aid flows increased by $65 \%$ during this same period, the share of total development aid to agriculture fell from $17 \%$ of total ODA in 1982 to only $3.7 \%$ in $2002 .{ }^{54}$ Only a few months before a global food crisis erupted, the World Bank's influential World Development Report reminded the aid industry of the importance of agriculture for development. After a surge in the price of basic foodstuffs and a series of food riots in 2007 and 2008, billions of dollars of aid are now being pledged for boosting agriculture in the developing world. Could this sad episode of collective misjudgement have been avoided? Finding a suitable allocation of funds across sectors is always a delicate balance, to which there can be no 'right answer'. In an industry where allotment choices are fully decentralised, its actors are bound to repeat this allocation mistake if they are not assisted by independent research and analysis on the resulting funding choices for the global public policy.

\section{Figure 8, Aid to agriculture in Subsaharan Africa, 5-year moving average, 1999 prices}

(Source: Carl Eicher 2003, p. 31. OECD/DAC statistics) ${ }^{55}$

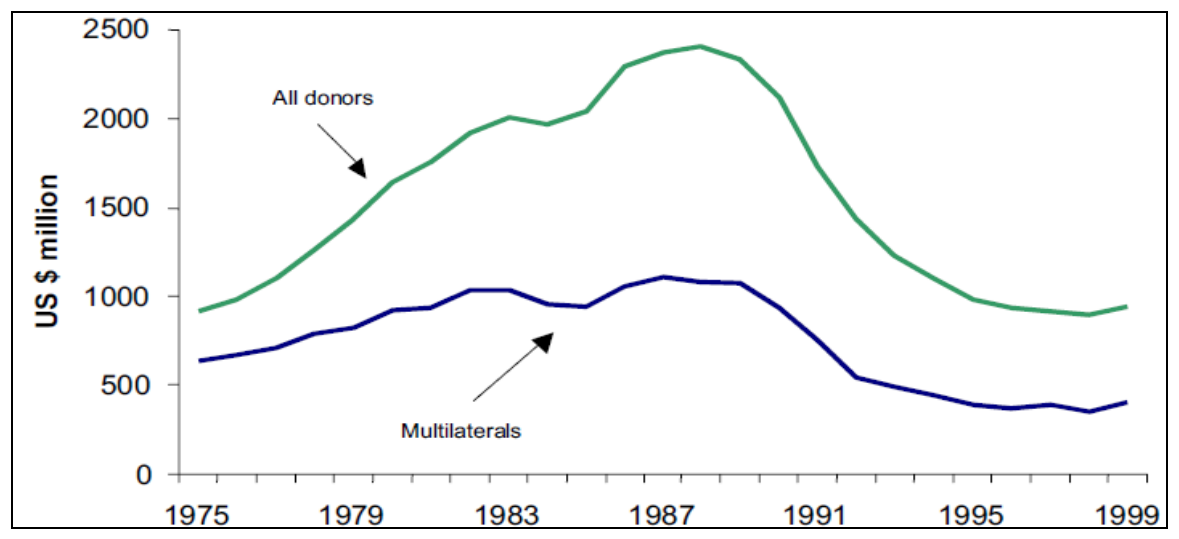

The evaluation gap is responsible for poor aid quality in another important way. In the aid industry as in any other, some actors are more effective than others. Yet development stakeholders from donor or recipient countries have no way of establishing who is better than whom at doing what. Whereas international rankings exist to rate the quality of universities ${ }^{56}$, too little is done in the way of evaluating donor performances based on the quality of the aid delivered $^{57}$. As a result, phoney NGOs or foundations roam in developing countries in the name

\footnotetext{
${ }^{53}$ Figures expressed in 2002 dollars

54 “DFID (2004), "Official development assistance to agriculture".

55 EICHER, C. (December 2003), "Flashback: Fifty years of donor aid to African agriculture," Michigan State University.

${ }^{56}$ These rankings may justifiably be contested and certainly ought to be improved; however they exist, which is a merit in itself.

${ }^{57}$ An important step to fill this gap has been taken by the International Initiative for Impact Evaluation (3ie). Cf. www.3ieimpact.org
} 
of development or humanitarian aid, burdening local administration for very poor development results. Some bilateral actors are accused of serving the commercial interests of their country at the expanse of the social and economic well-being of the host country. Yet no credible source of information is available to prove or disprove such claims - a situation that nurtures suspicion of development assistance as a whole.

\section{The capacity-building paradox}

A fourth market failure generates perverse incentives for donors. It is what we call the 'capacitybuilding paradox'. The lack of institutional capacities lies at the heart of underdevelopment, as it is both a cause and a symptom of poverty. And yet the weaker state capacities, the more donors tend to be massively present and design coordination mechanisms... that require high administrative capacities from the receiving state! The result is that donors spend much of their time and energy 'coordinating' without solving the weakness which is at the heart of the problem. The inability to tackle the capacity-building paradox is largely related to the pressure for immediate tangible results from which more and more development organisations are suffering. The Paris Declaration is the first international agreement on aid to mention capacitybuilding among its main objectives. However it can only rely on goodwill for its implementation: bilateral donors' preference functions are driven by rational choice, bounded by their capital and public opinion's preferences.

When they work in a project mode, donors have few incentives to generate long-term capacity, as they risk losing these capacities to other projects and donors - at typical case of the tragedy of the commons described by Hardin ${ }^{58}$. In a context where political premium for visible results and impacts keeps mounting, donor projects are too often driven by the quest for immediate solutions to highly-visible problems, to the detriment of the patient work of strengthening the local capacities that will be able to solve these problems in the long-run. The international community's efforts in the reconstruction of Afghanistan are a particularly telling example, where specialized donor-driven agencies or project implementation units are charged with delivering a given public good that weak public administrations do not have the capacity to deliver. This has a hidden cost, which takes the form of a serious blow to the legitimacy of the Afghan state ${ }^{59}$ - whose side-effects are all too clear, but too seldom taken into account. Global public policies that address long-term stakes fall on the same side of the "problem-solving versus capacity-building' dilemma. Take climate change: pressure for visible results creates an incentive for actors to report and communicate on the tons of carbon their projects saved for the world, rather than to invest in strengthening the domestic institutional capacities of developing countries to fight against climate change or adapt to it.

The problem is that donors are not rewarded for the public good they generate when they generate capacity, and pay no extra cost when they use existing capacities - such that the lowhanging fruits with small long-term development results remain much more appetizing than the projects that generate longer-term, higher development-return. This leads us back to where we left global public policies in our previous paper: indicators matter! We are forced to recognize that there are no credible indicators that can give credit to effective capacity-building efforts: build a well you are a hero (few will notice if it is dry two years down the road); help structure a well-maintenance system in a desolate area and you will have the hardest time raising money!

\footnotetext{
${ }^{58}$ HARDIN, G. (1968), "The tragedy of the Commons," Science, 162(3859), 1243-1248.

${ }^{59}$ MICHAILOF, S. (December 2009), "The Seven Capital Sins of the Donor Community in Afghanistan", GMF Policy Brief.
} 
Conventional wisdom holds that coordinated budget support is the way forward, as the ideal instrument to harmonise donor practices and improve government capacity. It is understood by many as a convincing response to the coordination troubles that gave rise to the Paris Declaration. Yet budget aid is no panacea either. While it can be an efficient way to disburse funds in countries with high capacities, these countries are precisely those that suffer least from donor proliferation and ill-coordination. On the other hand, in states with weakest capacities, the beneficiary cannot handle the large volumes of aid that it receives without deducting a high corruption or inefficiency toll. It may well be that the pressure to expand budget support despite the weakness of local financing systems ends up undermining aid efficiency rather than improving it. Herein lies the second face of the capacity-building paradox: as effective budget aid supposes the weak capacity issue resolved, the donor community is not responding to the institutional weakness that creates the need for coordination in the first place. Once again, the existing coordination mechanisms appear to be blind to the massive disparities in capacities in recipient sates.

\section{Engineering processes of hypercollective action}

Over the past decade, practitioners and academics have identified the growing chaos generated by the proliferation of actors of development assistance as a major source of inefficiency in aid delivery. As we have seen, the reaction has been to rush toward the field to build cooperation frameworks. Though useful and well inspired, these schemes have generally missed their goal: by overlooking the faulty incentive structures of aid actors, the international community has ended putting all the eggs of the effectiveness issue in the basket of the Paris Declaration - an attempt to reduce the complexity of the aid architecture through coordination.

Clearly, in spite of all its merits, the Paris Declaration does not provide solid enough ground on which to build the kind of hypercollective action that is required by $21^{\text {st }}$ century global public policies. Should the baby be thrown out with the bathwater? Not just yet: the improvements brought about by the Paris Declaration process are certainly welcome, and many lessons are still to be learned from this important experiment in collective policy-making. But it is high time for a new conceptual framework to emerge, one which will help shape dynamic processes of multiactor convergence that are more compatible with the political economy of international cooperation initiatives as they are taking shape in these early years of the $21^{\text {st }}$ century. This will imply getting the philosophy right, and getting the processes right.

\subsection{Getting the philosophy right}

\section{Facing complexity}

Let us come back to the concept of hypercollective action: hypercollective action is not just the product of the interaction between an increasing number and kind of actors in a given field of policy. More fundamentally, it is a new way of thinking, devising and implementing public policy in a world of 'evermore collective action'.

We have seen that what is at stake is not so much the proliferation of actors (a trend that is here to stay), but rather the effective management of this proliferation in a way that addresses the shortcomings of the political economy of international cooperation. Let us then consider how the 
evolution from collective to hypercollective action impacts the governance of the emerging global policy, and what role this leaves to the historical actors of international relations - good old nation states.

Conventional collective action in international relations typically involves the coordination of a limited number of relatively homogeneous actors, gathered in the name of their decision-making power to solve a given problem. In addition to the framework of international law, formal (IMF) or informal (G8, now G20) international regimes were instituted in the $20^{\text {th }}$ century to allow important stakeholders of a given issue to meet, discuss and eventually reach common decisions. What we are seeing with the explosion of the number and kind of actors that compose the embryonic global public policy is the extreme complexification of the processes of international cooperation and decision-making: as we have seen, hypercollective action concerns a much larger number of more heterogeneous actors, involved (rather than invited) in the discussion because they count among the policy's multiple 'stakeholders ${ }^{60}$. Looking at recent successes in international mobilization, one sees that the collective action of this constellation of actors has tended to structure itself through forums (such as the 'World Social Forum' or the 'World Economic Forum'), partnerships ('The Global Compact'), platforms ('Save Darfur coalition', Interaction, CONCORD or Eurodad), networks (Global Development Network, Development Gateway) and epistemic communities (materialized by thematic journals and think tanks). Whether formal or informal, these regimes have themselves become 'hypercollective'. In a way, the new generation of international policymaking is structured like a gigantic 'wiki- platform ${ }^{61}$, in which very different actors plug their concepts, strategies, instruments, and financial inputs. No single actor of the community is formally responsible for the final output - global public policies - whose objectives and instruments are in perpetual redefinition. As with any wiki, there is no fixed architecture: actors work on a perpetual 'beta' version.

Table 2, International regimes 2.0

\begin{tabular}{|c|c|c|}
\hline & Late $20^{\text {th }}$ century & Early 2000's \\
\hline \multirow{6}{*}{$\begin{array}{l}\text { Worldwide } \\
\text { web }\end{array}$} & Web 1.0 & Web 2.0 \\
\hline & $\begin{array}{l}\text { 1. Architecture of information through single } \\
\text { editing: website as content delivered by a webmaster } \\
\text { to internet users }\end{array}$ & $\begin{array}{l}\text { 1. Architecture of participation through open editing: } \\
\text { website as an interactive platform with real-time input from } \\
\text { internet users }\end{array}$ \\
\hline & $\begin{array}{l}\text { 2. Static architecture and content between two } \\
\text { updates }\end{array}$ & $\begin{array}{l}\text { 2. Perpetual 'beta' version: the architecture and content are } \\
\text { continuously shaped through an ongoing process of } \\
\text { collaboration that constantly changes the Web site } \\
\text { landscape }\end{array}$ \\
\hline & $\begin{array}{l}\text { 3. Passive community that absorbs available } \\
\text { information - and possibly reacts by contacting the } \\
\text { webmaster through a bilateral relationship }\end{array}$ & $\begin{array}{l}\text { 3. Active wiki communities and social networks that share } \\
\text { information, knowledge and opinions in a multilateral } \\
\text { relationship }\end{array}$ \\
\hline & 4. The owner of the website finances its activities & $\begin{array}{l}\text { 4. All members of the network are invited to donate to } \\
\text { finance its upkeep }\end{array}$ \\
\hline & 5. Content is typically protected by copyright & $\begin{array}{l}\text { 5. Open source software and 'creative commons' licenses } \\
\text { are typically used, which favours reproduction of content }\end{array}$ \\
\hline \multirow{2}{*}{$\begin{array}{l}\text { Inter- } \\
\text { national }\end{array}$} & International regimes & International regimes $\mathbf{2 . 0}$ \\
\hline & 1. International policies are designed by states. & 1. International policies are shaped and delivered by all \\
\hline
\end{tabular}

${ }^{60}$ SEVERINO, JM. and CHARNOZ, O. (2008), De l'ordre global à la justice globale: vers une politique mondiale de régulation, vol. 2. En temps réels, 9.

${ }^{61}$ A wiki is a website that allows users to create and edit of any number of interlinked web pages. 


\begin{tabular}{|c|l|l|}
\hline $\begin{array}{c}\text { collective } \\
\text { action }\end{array}$ & Non-state actors can react to the policy choices & $\begin{array}{l}\text { stakeholders (states, NGOs, foundations, local authorities, } \\
\text { businesses, epistemic communities, bilateral and } \\
\text { multilateral authorities...) in various forums }\end{array}$ \\
\cline { 2 - 3 } & $\begin{array}{l}\text { 2. The architecture and policy content of collective } \\
\text { action is stable from one official summit to the next }\end{array}$ & $\begin{array}{l}\text { 2. The architecture of collaboration is perpetually } \\
\text { redefined by ad hoc coalitions of actors gathering around } \\
\text { given topics }\end{array}$ \\
\cline { 2 - 3 } $\begin{array}{l}\text { 3. The negotiators of international policies has only } \\
\text { slow and formal collaboration processes }\end{array}$ & $\begin{array}{l}\text { 3. The designers of global public policies exchange } \\
\text { information, knowledge and opinions in real time }\end{array}$ \\
\hline $\begin{array}{l}\text { 4. States finance the bulk of cooperation efforts } \\
\begin{array}{l}\text { 5. Each organisation designs its own learning } \\
\text { processes (evaluations, training) to improve its } \\
\text { effectiveness }\end{array}\end{array}$ & 4. All stakholders bring inputs into the policy \\
\hline
\end{tabular}

One of the benefits of these new collaborative processes of international policymaking is that, although hypercollective motion necessitates a critical mass of actors progressing in the same direction, it does not require that every single actor concerned follows suit. Unlike some international negotiations that need unanimous backing to progress, it is much more efficient to spend time and effort ensuring that the median player is comfortable with the direction or that the front-runners are exploring the right innovative paths than convincing the last naysayers that they should join the movement.

On the other hand, it seems utopian to hope to plan or coordinate the action of this polycentric group of actors: in fact independence from political authority is a guiding principle for many actors of global public policies. As Owen Barder puts it for the field of development assistance, "we are reaching the limits of what can be achieved by better planning to improve aid" 62 . There is no future in planning as a way to improve aid, or indeed in the delivery of any global service or policy characterized by hypercollective action. What ought to be possible, however, is to provide a framework to orient the direction of its atomized group of players, one that will help make their trajectories converge in a more focused flow. This is what Nehmat Shafik advocates in a blog post entitled 'From Architecture to Networks: Aid in a World of Variable Geometry' ${ }^{63}$. Pierre Jacquet argues that efficient international cooperation could be structured though a 'network of overlapping networks', and holds that each of these networks may develop its own principles of collective action provided there is mutual recognition between networks ${ }^{64}$.

To follow the wiki metaphore, improving the coherence of 'global policies 2.0' will require designing the most efficient mechanisms to regulate this 'architecture of participation'. Depending on the characteristics of the public policy, its players and objectives, this may require drawing more extensively on market-based, networks-based or more traditional rule-based cooperation models.

\footnotetext{
${ }^{62}$ BARDER, OWEN (2009), op cit.

${ }^{63}$ SHAFIK, M. (2009), 'From Architecture to Networks: Aid in a World of Variable Geometry'. Ideas4development.org

${ }^{64}$ JACQUET, P. (2009), "Addressing the Over-complexity of the International Aid Architecture," Contribution to the Global Agenda Council on Poverty and Development Finance.
} 


\section{Shaping complexity}

Where does this leave the historic actors of international collective action? Globalization enthusiasts who announced the dissolution of the nation state for the turn of the century are in for a big surprise: the era of global public policies and hypercollective action will not be that of states' evanescence, quite the contrary. In fact, the series of global crises of the early $21^{\text {st }}$ century have seen the comeback of states as actors of international relations. The 9/11 attacks has led several countries to tighten border security, in some cases constraining international travel considerably. The 2007 and 2008 food crisis has led some states to reduce or stop their food exports for the sake of national food security. In their fight against the H1N1 pandemic, governments have ordered vaccines for their own populations, with little regard to the capacity of international pharmaceutical companies to deliver them - or, for that matter for poorer countries to afford them. Finally, the financial crisis has led states to bail out banks by nationalising what they considered as key national assets. Clearly political authority remains in high demand, and continues to lie essentially with national governments.

How does this recent trend of state resurgence fit with that of the increasing weight of non-state actors on the international scene? Both of these tendencies are compatible with - in fact, constitutive of - hypercollective action. It is a mistake to think the expansion of non-state actors and the continued presence of states in international relations as antagonistic. As they will continue to coexist in the management of international policy, both state and non-state actors will need to find new ways of interacting in the definition of public goods and in the structures to deliver them.

Complexity is built into the fabric of global public policies ${ }^{65}$. This complexity is neither 'good' nor 'bad'; it is an inescapable fact of early $21^{\text {st }}$ century international relations - one that is likely to stay, as the Copenhagen negotiations have shown. What is urgently needed is to make sense of this complexity. And, because the forces that engender it (proliferation, fragmentation...) can help or handicap the delivery of efficient international services where they are needed, it is fundamental that this complexity be shaped politically so as to minimize the risk of chaos it generates while preserving its fruitful diversity. Rather than attempting to reduce or even manage this complexity as the Paris Declaration has attempted to do in the field of aid, what is needed is to steer it towards greater effectiveness.

Public authorities have a fundamental role to play in steering this complexity in a way that provides the best possible fit between the supply of global public policies and the demand for 'global public services' (i.e. efforts to guarantee a stable climate, to ensure a reasonably secure international and local environment, to preserve humanity from the spread of global pandemics, etc.). The challenge of hypercollective action and the stakes linked to its success will push national and regional political authorities to set their violins aside to reposition themselves as the conductors of a grand polyphonic symphony. As trustees of the public good, their collective task is to structure global hypercollective action into relevant, coherent and effective global public policies to deal with the most crucial threats to global prosperity.

What are the instruments available to steer the coalition of actors of global public policies? As we have seen, different modes of collaboration coexist, and can be drawn upon to make actors' expectations converge. We have identified five: rules, systems of incentives, discourses,

\footnotetext{
${ }^{65}$ We would like to thank the Center for the Study of Global Governance of the London School of Economics for a very productive brainstorming session on these concepts - from which we draw in this paragraph - and especially Mathias Koenig-Archibugi for his analysis of 'complexity'.
} 
networks and norms or standards. Because each of these modes of collaboration affects different actors differently, none in itself is any longer sufficient to generate effective collective action. Successes of international cooperation such as the mobilization in favour of antiretroviral treatment $^{66}$ show that when they are effectively combined, they can produce extremely convincing results. Each of them can be thought of as a thread. The challenge ahead lies in knitting each of these threads so as to generate the fabric of effective hypercollective action.

Table 3, Five threads of hypercollective action ${ }^{67}$

\begin{tabular}{|c|c|c|c|c|c|}
\hline $\begin{array}{c}\text { Threads (modes } \\
\text { of } \\
\text { collaboration) }\end{array}$ & $\begin{array}{l}\text { Rules and } \\
\text { agreements }\end{array}$ & $\begin{array}{l}\text { Norms and } \\
\text { standards }\end{array}$ & $\begin{array}{l}\text { Systems of } \\
\text { incentives }\end{array}$ & $\begin{array}{l}\text { Information and } \\
\text { discourses }\end{array}$ & $\begin{array}{l}\text { Networks and } \\
\text { partnerships }\end{array}$ \\
\hline Forms & $\begin{array}{l}\text { - International } \\
\text { agreements, laws } \\
\text { and covenants }\end{array}$ & $\begin{array}{l}\text { - Formal or } \\
\text { informal } \\
\text { norms }\end{array}$ & $\begin{array}{l}\text { (+) Rewards } \\
\text { (-) Threats }\end{array}$ & $\begin{array}{l}\text { - Cognitive frameworks } \\
\text { - Ideologies } \\
\text { - Information }\end{array}$ & $\begin{array}{l}\text { - Global partnerships } \\
\text { and alliances }\end{array}$ \\
\hline Examples & $\begin{array}{l}\text { - Paris } \\
\text { Declaration } \\
\text { - Kyoto Protocol }\end{array}$ & $\begin{array}{l}\text { - International } \\
\text { accounting } \\
\text { standards } \\
\text { - Fair Trade } \\
\text { standards } \\
\text { - 'Sphere } \\
\text { standards' }\end{array}$ & $\begin{array}{l}\text { (+) Advanced } \\
\text { market } \\
\text { commitments } \\
(-) \text { 'Fossile of } \\
\text { the day' } \\
\text { awards in the } \\
\text { climate } \\
\text { negotiations }\end{array}$ & $\begin{array}{l}\text { - The 'Responsibility to } \\
\text { protect' } \\
\text { - The moral duty of } \\
\text { international solidarity } \\
\text { - Interactive maps of } \\
\text { 'who does what' in an aid } \\
\text { recipient country }\end{array}$ & $\begin{array}{l}\text { - Critical Ecosystem } \\
\text { Partnership Fund } \\
\text { - 'Save Darfur' } \\
\text { coalition } \\
\text { - European } \\
\text { Development Finance } \\
\text { Institutions }{ }^{69}\end{array}$ \\
\hline
\end{tabular}

Beyond the promising intuition that international collective action will increasingly take the form of networks of actors, and that it will necessarily draw from various modes of collaboration, the concrete way to move from ill-fated attempts at 'harmonization' to new paradigms of regulation largely remain to be invented - a daunting task, on which this last section of the paper proposes to venture a few preliminary suggestions.

\subsection{Addressing specific gaps in the market of global public policies}

After a long trip in the austere backrooms of global public policies, it is now time to embark on a little institutional architecture exercise, and to put forward a few very concrete propositions on what structures and processes of hypercollective action could look like.

As we have seen, the Paris Declaration has so far been the most important effort to harness the 'hypercollective' in the development aid ecosystem. Yet it stems from an imperfect analysis of the political economy of this burgeoning global public policy. It focuses on local issues (thus losing sight of upstream incoherence), it assumes that donors are driven by a single preference function, it sees aid recipients as a homogeneous whole, and it relies excessively on two modes of collaboration (rules and standards) to the detriment of the three others. Improving actors'

66 KAPSTEIN, E., and J. BUSBY (2010), "Making Markets for Merit Goods: The Political Economy of Antiretrovirals," Center for Global Development Working Papers, 1(1).

${ }^{67}$ Adapted from SEVERINO, CHARNOZ, op.cit.

${ }^{68}$ An example of such a scheme is the Development Assistance Database developed with the support of UNDP in the Central African Republic.

${ }^{69}$ EDFI, see: http://www.edfi.be/ 
performances in the delivery of their share of the collective good will imply building a more comprehensive framework of cooperation for the provision of global public services - one which builds on the five threads of hypercollective action. The last section offers a few suggestions on how to take a few steps in this direction. It looks at whether fresh ideas could emerge from placing additional emphasis on the 'incentives' and 'discourses' that drive the actors of global public policies, as well as improving the networks through which they collaborate and the standards around which they make their actions converge. It suggests a new ambition for multilateral organizations - one which would turn them into the agents of hypercollective action.

\section{Informing the policy}

We have shown how incoherent policy choices could originate from diverging preference functions of the various constituencies of aid. Making the supply of aid more responsive to the demand side's needs, we argued, implies incorporating as much as possible of final beneficiaries' priorities in the preference functions of donor constituencies in the North (and in those of recipient state authorities). Though this will remain a challenging issue in the world of hypercollective action, reducing asymmetries of information in the aid market is a fundamental step to bridge the awareness, consent and accountability gaps.

\section{Public information to shareholders}

The first corollary of this statement is that public information is no trivial task, but one of the important means to improve the effectiveness of global public policies. Why is public money spent on biodiversity protection, conflict management, poverty reduction or climate change mitigation projects on the other side of the globe, when donor countries are themselves confronted with poverty, insecurity and environmental degradation? Actors of international cooperation tend to forget that the answers to such questions are not self-evident: the evolving rationale for North/South collaboration needs to be explained ${ }^{70}$. Spontaneous awareness of these needs is typically very low: the stakes of the global public policies are complex, the projects they fund often thousands of miles away from the taxpayer, and their impacts measurable years after the initial decision to finance a given operation has been taken.

Transparent and accessible public information is the price to pay for the kind of support that is required for a sustained public effort in favour of global public goods. Taxpayers are the shareholders of these policies; without their consent, the public resources that irrigate bilateral, multilateral, but also NGO and philanthropic efforts will quickly dry up. As shareholders, they need to be convinced that the right allocation choices are being made. This is what efforts towards public accountability are about. With a few remarkable exceptions, communication efforts towards the public opinion of OECD countries to explain the rationale for international cooperation have been limited. A survey undertaken in Europe shows that the countries that dedicate most resources to development aid are also those who communicate most about it. Do governments communicate on international solidarity because they do comparatively well in terms of public generosity, or do they do better than others because they communicate about this specific policy? The causality probably runs both ways. The remarkable coherence of Sweden's development aid policy, for instance, and the overall strategic alignment of Swedish government and civil society, anyway suggests that a virtuous circle can be made to exist.

\footnotetext{
${ }^{70}$ The changing rationale of development aid is described in The End of ODA - Death and Rebirth of a Global Public Policy, op cit.
} 


\section{Voice of consumers}

The battle for better information and accountability also implies increasing the direct feedback from beneficiaries, i.e. fixing what Owen Barder calls the 'broken feedback loop' ${ }^{71}$. Though many development programs are assessed by development agencies through thorough investigations, beneficiaries (civil society, governments and final beneficiaries) are seldom consulted in a serious way. In most cases, they cannot assess and challenge the relevance and quality of the programmes designed by the aid agencies. Providing professional $360^{\circ}$ assessments and ratings of individual agencies, foundations and NGOs as well as country programmes of each donor, and giving them wide publicity especially in donor countries should help not only improve the quality of each programme, but also provide better indications on the real demands of the beneficiaries. This should progressively help align private and public donors on the real priorities for the country by bringing better information on local expectations to the policy's constituents in donor countries.

If it is to improve the coherence of aid choices, such a vast information effort on the foundations for global public policies will need to give voice to civil societies of developing nations, as they are often the best advocates of their cause and the best judges of aid's ultimate effectiveness. This battle for the general public's awareness cannot be carried out by states alone: it requires a collective effort by coalitions of NGOs, think tanks, bilateral and multilateral institutions philanthropic actors and celebrities such as the ones that mobilised in favour of the populations of Darfur, the victims of the Haiti Earthquake or the democratization of ARV treatments. Collective communication efforts not only increase the level of information and public support for the policy, but it also creates alignment: indeed, the need to create public discourses forces NGOs and state authorities to discuss on the substance of the discourse.

\section{Indicators for stakeholders}

Finally, reducing asymmetries of information calls for developing robust performance indicators, more strongly correlated to global public policies' ultimate goals. Today, these concrete assessments of donor assistance results in health, education or environmental protection are rare. It should come as no surprise that aid remains hostage to second-order priorities, such as project visibility or meaningless technocratic measures of national generosity. What the policy needs, therefore, are indicators of impact that would allow its different stakeholders to assess aid quality and effectiveness according to its proclaimed objectives: effective contributions to economic growth, the preservation of global public goods, or poverty reduction. What we aim to achieve is what we ought to be measuring! Although rigorous indicators of results are notoriously difficult to achieve, not least because of the methodological difficulty in attributing success, they are the key to sustained public support for global public policies. As such, they ought to be one of the areas of concentration of collaboration efforts between actors of the field. We will come back to ways in which this could be done.

To sum up, one of the important ways to avoid incoherent funding choices is to contribute to the convergence of stakeholder preferences through: 1) communicating much more actively on the ultimate objectives of the policy to domestic constituencies; 2) giving voice to final beneficiaries; and 3) building proper indicators of aid's contributions to its ultimate goals.

\footnotetext{
${ }^{71}$ BARDER ,O. (2009), op cit.
} 


\section{'IPCCs' for development aid and other global policies}

Despite recent accusations of partiality, the International Panel on Climate Change (IPCC) has proved remarkably effective over the last decades in making science, public awareness and policy converge toward concrete actions. This intergovernmental body was established to provide decision-makers and the general public with an objective source of information about climate change and its threats. Its reports, which are neutral with respect to policy, analyse projected impacts and outline options for adaptation and mitigation. They serve as the main reference for the international negotiations on climate change mitigation, and provide invaluable information to the media.

The UN could gather a community of highly respected scientists, academics and professionals, under the independent chairmanship of a 'wise man/woman', with the objective of providing authoritative knowledge and information on global public concerns and their evolution. It would give them the mandate to provide regular reviews on the needs for global collective services and current policy choices. While raising the profile of the international cooperation, this would help combat sectarian ideologies and petty interests, cast light on difficult policy choices, and provide a clear overview on which decision-makers could base their judgement. It would survey existing practices of global public policies (global funding allocations, strategies and instruments) and suggest possible arbitration decisions, so as to limit the effect that we referred to earlier as 'trendy aid'.

Decision-making is an inherently political function, and should remain so. But outlining possible policy options and instruments available to deal with a given ill, their likely costs and their expected impacts does not need to be. Informing and depoliticizing this crucial step of policymaking would help rationalise decisions that are presently taken according to political authorities' best judgement - and the capacity of lobbies to plead for their cause. Although this public information in itself would not stop poor or even irrational allocation decisions, it would increase the accountability of political authorities for their choices.

\section{Incentivizing the policy}

At this point, some readers will be asking what can possibly make the authors think that the various actors of global public policies would spontaneously accept to move towards constraining forms of collaboration for the sake of collective efficiency.

And justly so: in the absence of any overarching authority in the aid market, awareness of the costs of proliferation, fragmentation and ill-coordination will not by itself lead those responsible for these ills to change their practices. For the same reason that some actors of development aid can simultaneously agree with the principles of the Paris Declaration and resent applying them to their own work in practice, most institutions will resist moves to cooperate in the absence of credible incentives. As economists put it, suboptimal equilibriums can be extremely stable when those who need to act to improve the situation do not bear the bulk of its costs, and would benefit marginally from the gains. Because it would be illusory to dream of piloting every actor in any centralized way, what is needed is to drive the drivers of change. As in any collective action problem, part of the solution therefore lies in developing the right system of incentives - sticks and carrots for actors to make their practices converge.

\section{Sticks...}

Negative incentives would need to punish ill-performing actors of international cooperation (assessed according to the common performance standards to which we will turn) and those 
actors who refuse to enter in collaborative working modes (i.e. the free riders of cooperation efforts). In the absence of a strong and legitimate overarching authority, it is difficult to envisage mechanisms to discipline free-riders and ill-performers of the development aid, humanitarian relief and global public goods industries other than of a reputational nature. Yet credible fingerpointing exercises can be extremely effective in a business where reputation is a key element of success - as the considerable impacts of certain media, NGO and think-tank reports have shown in the past ${ }^{72}$.

Some existing instruments, such as the OECD DAC's peer reviews, the Center for Global Development's 'commitment to development index' or the recent 'International Initiative for Impact Evaluation' have this naming and shaming dimension. What the field is missing however are independent mechanisms to evaluate the impacts of international aid on a given country or sector. How effective are the donor community's combined efforts in Cambodia or the DRC? What can be improved in the international efforts for the protection of biodiversity? Such crossdonor evaluation exercises would help point out in each country or sector which donors are playing the collective action game constructively, and which are free riding on others' collaborative efforts. They would also help fight the marginal player syndrome by naming-andshaming donors that show poor performance according to standard metrics for success - rather than those who do not stick to the trendy idea of the day. This again underlines the need for a credible evaluation function at the international level, capable of shaming actors into collaborative attitudes.

Some specific sectors of the global public policy are equipping themselves with such cross-donor evaluation tools. The field of microfinance lived through a surge of actors and funding in the mid-2000's. The dramatic rise in funders posed a risk to the quality of the projects, such that a group of donors decided to set up an evaluation process, and to entrust an independent policy and research centre with the mission to carry it out. In addition to its work on quantifying and analyzing global funding flows in the field of microfinance, $\mathrm{CGAP}^{73}$ now counts among its missions to improve the transparency around the performance of various funders. Its SmartAid for Mircofinance Index ${ }^{74}$ measures how well donors are set up to support microfinance, outlining strengths and areas of improvements. It draws on the good practice guidelines established over time with the Centre's different members, and a body of knowledge developed through peer reviews, country reviews and portfolio reviews. Rather than going down the route of the polite DAC peer-review process, each audited donor is given a score, which reflects its performance on five areas agreed by all funders as critical for effective microfinance: strategic clarity, accountability for results, knowledge management and appropriate instruments. Tens of donors are audited every year, including some of the field's largest actors - which is likely to push other microfinance actors to be audited and awarded a mark.

The results so far are inspiring. The CGAP review process has convinced some actors to opt out of microcredit, and provided others with incentives for changing their ways of doing business. Given the success of the CGAP experience in the field of microfinance, other global public policies could equip themselves to assess the quality of outputs delivered by different types of actors along similar principles of organisation. Their reunion in a network could eventually take the form of a more comprehensive evaluation platform of global public policies.

\footnotetext{
${ }^{72}$ We refer here to the reports that first denounced employee working conditions in sweatshops of international footwear companies in the 1990's, yearly reports such as Transparency International's report on corruption or the release of information regarding sexual abuses in Peacekeeping operations.

${ }_{74}^{73}$ Consultative Group to Assist the Poor, http://www.cgap.org/p/site/c/aboutus/

${ }^{74} \mathrm{http} / / /$ www.cgap.org/p/site/c/template.rc/1.26.3224/
} 


\section{An evaluation platform for global public policies}

An independent evaluation platform could be set up to review in a structured, transparent and open manner global public policy performance at the geographic (country by country), thematic (policy by policy) and actor (donor by donor) level. It would draw on the capacities of many universities and think tanks, to provide the international community with independent evaluations.

Its objective would be to evaluate more systematically the overall impact of international cooperation initiatives in given countries and sectors. It would thus name-and-shame illperforming actors of global public policies and free riders of cooperation efforts - be they states, transnational companies, multilateral organisations, NGOs or philanthropic foundations. In doing so, it would need to look beyond the strict perimeter of development assistance, and assess the broader coherence of these different actors' strategic choices. The power of such an instrument is that it does not require consensus from all parties in order to be effective: a given player may object to the legitimacy of the evaluation, but nevertheless resent being stigmatized if a sufficiently large amount of its peers give credit to the evaluation process. If the evaluating authority has sufficient credence, the very risk of being stigmatized would progressively lead actors to opt out of sectors or countries where they have little added-value and progressively enter into accepted convergence mechanisms.

There is no time to stay polite. The stakes of global ills are too high for endless diplomacy: the international community is in a dire need of a credible independent evaluation platform for global public policies.

\section{... and carrots}

Positive incentives would also need to entice actors of international cooperation in spending time and energy looking for compatible strategies or common solutions to global problems.

In fact, European development aid has recently gone down this road, in a pragmatic and flexible approach to donor coordination. Several instruments have been set up over the last years to provide incentives for innovative collaboration and co-financing between European donor agencies $^{75}$. The European Commission has a special role in these instruments: rather than implementing the projects as any other donor, it provides the framework through which multiactor convergence happens, and an important financial incentive for donors to team-up to provide a collaborative solution to local development problems. It is worth taking a moment to describe how one of these instruments works.

The European Union's Strategy for Africa, published in 2005, set the broad objective of 'interconnecting' Africa in terms of transport, water, energy and telecommunications. To this end, in 2006 the EU-Africa Partnership on Infrastructure was endowed with a Trust Fund to speed up regional projects. The Infrastructure Trust Fund, managed by the European Investment Bank (EIB), is funded jointly by member states, bilateral agencies and the European Commission. It subsidizes the financing of infrastructure projects - mostly those included on the list of the New Partnership for Africa's Development (NEPAD, 2001). Subsidies reduce interest rates on loans from donors who co-finance the projects. The Commission, which chairs the

\footnotetext{
${ }^{75}$ We refer to the European Neighbourhood Investment Facility, the Infrastructure Trust Fund for Africa and a more recent European multi-donor partnership on education.
} 
Fund's executive committee, promotes projects considered as priorities by the beneficiaries thus ensuring the recipient country's ownership. The beneficiary is involved in project preparation from the design stage through to the financing proposal, and gives its assent to the terms and conditions of the loan. The general rule is to use national systems for project implementation, rather than donor procedures. If the local rules of procurement do not provide sufficient guarantees, those of the consortium's 'lead donor' apply.

One of the original elements of this fund is that it encourages co-financing: once projects are identified with partners in the South, they are discussed by European donors and put forward as loan applications. Loan applications are forwarded by a designated 'lead donor' to the Fund's executive committee. Once the loans are approved, the Commission disburses a subsidy to the lead donor, in charge of implementing the program. Co-financing under the delegated authority of lead donors constitutes a form of delegation of funds from the members of the trust fund to the lead donor. This collaborative formula has led to policy dialogue among the group of donors, and a gradual convergence of standards. The Commission's financing has brought incentives for bilateral European actors to collaborate - but left them free to decide whom they wished to partner with, and how they wished to organise their partnership. This has contributed to the mutual recognition of procedures by $\mathrm{AFD}$, the $\mathrm{EIB}$ and $\mathrm{KfW}$, and to the harmonisation of the criteria for evaluating loan applications.

Such innovative forms of collaboration between bilateral and multilateral actors of international policies nuance the traditional divide between national and international institutions. It creates a new stage of collective action. What are the ingredients working behind this innovative model of 'plurilateral action'? First, as in poker, every actor needs to contribute financially to the common pool in the form of an 'entry ticket' (which could be made to vary according to institutions' capacity to pay, so as to include actors of different financial capacities). Being part of a club has a cost. Second, considerable additional funding is provided in the form of a 'top-up' by a multilateral institution (in this case, the European Commission), which gains considerable weight in the allocation decision. Thirdly, a board composed of the different stakeholders decides in a collegial fashion on the objectives pursued and the conditions for eligibility (which, in this case, includes effective alignement on donor country strategy). Fourthly, a premium is given to multiactor projects, so as to encourage 'learning by doing' by its members and promote economies of scale.

This scheme of inter-donor cooperation provides a model of pragmatic hypercollective action. Replicating it would call for an important paradigmatic shift for multilateral institutions. Indeed today, multilateral institutions involved in international assistance and endowed with operational budgets (such as the World Bank, the European Commission or the UNDP) often operate as if they were ' $n+1$ donors': they devise, finance and implement projects and programs in the countries they assist in much they same way as other actors of the field do. The paradox is that in host countries where donors abound and aid absorption capacity is scarce, they are in competition with other actors of international assistance to finance health, microfinance, education or environment programs (including with the bilateral agencies of countries who sit on their boards!).

Bilateral and multilateral organisations can clearly do better than form the loose grouping of competing institutions that they currently form. This can be seen as a fantastic waste of potential considering the huge added value of multilateral actors, compared to the multitude of other actors present in the field of global policies. What is multilateral organisations' built-in added value? Reaching threshold effects by pooling large volumes of resources; 'industrialising' projects through the replication of pilot schemes; setting international standards (such as those 
that serve as the backbone of the Clean Development Mechanism for instance); gathering information and knowledge; providing multi-actor forums and setting up mechanisms through which other sets of actors can collaborate...

In a well-run world of global public policy, the main role of multilateral organisations should be to organise and finance collective action between the other players of global public policies. This would give all its sense to the pooling of national resources. The financing of a bilateral actor by a multilateral institution is sometimes perceived as a way to 'renationalise' or 'contract out' global public policy. But this is a narrow and corporatist way of envisaging multilateral action as if multilateral institutions had to defend 'their' funding and prerogatives.

Turning multilateral organisations into agents of hypercollective action will require that they perceive their role as platforms for multi-actor cooperation. As such, they could be the organisers and rewarders of cooperation, and the vectors of harmonisation between the field's different actors. This would allow them to focus on what they do best: setting the stage for effective hypercollective action. We understand that this would be a major change in their practices. Consider the response to the Haiti earthquake: instead of setting up a trust fund whose projects would be implemented by their teams, the World Bank and UNDP could use the trust fund's board to define a common policy framework to which all actors wishing to benefit from trust funding (NGOs, bilateral organisations or foundations) would adhere. Instead of being implementation agents, these multilateral organizations would become 'rewarding' and 'incintivizing' agents, which could considerably improve the coherence and thus the efficiency of the overall reconstruction effort.

\section{'Top-up schemes' to deliver assistance through multi-actor coalitions}

One of the ways in which convergence can be encouraged is by giving multilaterals responsibility of 'top-up schemes', explicitly designed to reward collaborative work between different actors of global public polices. The EU's Infrastructure Trust Fund for Africa described earlier could serve as a model for this type of multi-stakeholder collective action. Such schemes could be stepped-up considerably, and adapted to different contexts to best fit the needs expressed by the intended beneficiaries.

They should first be developed in fragile and post-conflict states, where donor coherence is most crucial, absorption capacities most problematic and financing needs most dire ${ }^{76}$. However such 'top-up schemes' could serve in other contexts, and inspire the practice of vertical funds. In this respect, the climate negotiations offer a wonderful opportunity to advance in the right direction. At the time this paper is written, the world is due to launch a new climate change fund. Rather than building yet another standard vertical fund for environmental protection, this global fund could be designed along the lines of a 'top-up fund' with the triple objective of 1) starting from local demand rather than global supply; 2) using a diversified pool of financial and technical instruments; 3) and encouraging locally-anchored and multi-actor efforts.

Coalitions of actors already working on these issues (NGOs, foundations, bilateral development agencies...) could apply for complementary funding on top of existing programmes. Projects would only be eligible for 'top-up funding' if their sponsors: 1) are in line with the trust fund's strategy (i.e., fit to the geographic and thematic priorities outlined by its statutes); 2) submit the project as part of coalition; 3) define agreed outputs of the project according to standard

\footnotetext{
${ }^{76}$ RAY, O., and J. WHITE (August 2009), "Strengthening Transatlantic Policy Coherence in Fragile States : Afghanistan as a Laboratory for Solutions", GMF Policy Brief.
} 
measures of output; and 4) agree for the project to be audited by the evaluation platform mentioned above.

\section{Generating common norms, standards and objectives}

The global financial crisis has shown that the proliferation of actors and instruments in underregulated markets can be a factor of fragility for the system as a whole. But is proliferation or illregulation the problem? What makes a market efficient is not the reduction in the number of its actors, or even the coordination of their strategies. On the contrary, efficient markets thrive because companies have different strategies. If it isn't 'harmonisation' or 'integration', what makes a market efficient?

What ultimately counts is the existence of an established framework within which actors can safely compete and innovate. On top of asymmetries of information and insufficient incentives to cooperate, the market for aid as it stands suffers from the weakness of its norms and standards, and the absence of a general sense of direction. A more explicit normative framework for the emerging global public policies could provide the canvas in which organizations' practices will gradually converge. By making every actor's efforts compatible, it would allow for their impacts to add up. Two sets of norms will need to be developed in the years to come.

The first are common 'accounting' standards, so that all aid actors develop compatible languages of inputs and results. We have seen that global public policies have inadequate measures of policy inputs, outputs and impacts ${ }^{77}$. The consequence is that it is difficult to compare the respective efforts made by donors, and to evaluate the efficiency of their action. Developing common benchmarks of effort and metrics of success is one of the keys to improving aid effectiveness.

\section{An international accounting standards board}

We have seen that the role of multilateral organisations should evolve so as to allow them to concentrate on what other actors cannot do. Beyond their twin role as financers of cooperation and rewarders of convergence mentioned above, they should push their advantage as poles of experience-sharing and standard-setting for all actors of global public policies. By opening to the field's more recent actors (emerging donors, NGOs, foundations, etc.), multilateral organisations can be the place where aid actors negotiate common norms and standards.

This has already been done: through patient work involving many different actors of humanitarian aid, the Sphere Project has devised a series of internationally-recognized standards for the delivery of humanitarian aid $^{78}$. The OECD DAC, enriched with representatives from the whole range of institutions active in global public policies, could serve as the focal point for the emergence of alternative measures of inputs and impact of international cooperation - i.e. serve as the 'International Accounting Standards Board' of global policies.

The new Board could begin this process by unbundling 'ODA', i.e. looking into complementary ways of measuring financial inputs into the delivery of essential services, the promotion of given global public goods or economic convergence. It could, for example, investigate a measure based on budget costs, and one on overall financial volumes dedicated to these objectives.

\footnotetext{
${ }^{77}$ The End of $O D A$, op cit.

${ }^{78}$ http://www.sphereproject.org/
} 
Measuring inputs, however, will not suffice; it should also investigate ways of measuring the different outputs of global public policies. The first step would be to share practices regarding the elaboration of results-based indicators, such as what is being done to achieve compatible measures of the reduction of $\mathrm{CO} 2$ emissions. As common methods are found to measure the tons of carbon emissions reduced, common methods could be devised to evaluate the number of schoolchildren sent to school, or the improvement in the quality of the schooling they receive. Many other international standards could be produced and progressively refined through such a project, to measure policy impacts in the domains of health, food security, etc.

Another important result these international measurement tools should try to assess is international contributions to local capacity-building. This would facilitate giving credit to crucial capacity-building efforts that are today the work of a few enlightened institutions. The improvement in the quality of institutions and governance will need to be put at the forefront of policy output performance indicators. This is in no way easy, but agreeing on a solid capacity and institutional capacity index is now within reach.

The second set of common standards that is urgently needed is a set of agreed objectives, so as to ensure that all actors of global public policies pull in the same direction.

The aid industry has long suffered from confusion between goals and instruments: while the objective of greater effectiveness implies that all actors of global public policies should be working towards common goals, it makes little sense to harmonize the strategies and instruments they deploy to reach them. Yet development orthodoxies have tended to harmonize strategies while changing over time the objectives of what they are expected to achieve. On the contrary, what the international community needs is a broad set of common goals towards which all actors deploy their energy. In order to be effective, these need to be compatible with development's timeline, and therefore remain stable for longer than a decade. The MDG framework, provided it is understood as outlining common objectives of end-results rather than mere input allocation grids $^{79}$, can provide the basis for such agreement on global public policies' goals. The reflections on the MDGs post-2015 would provide a good occasion to review these objectives and clarify their meaning. We shall come back to this point in a following paper.

Naturally, these sets of common norms and standards will not arise spontaneously. Luckily, the $20^{\text {th }}$ century has bequeathed a dense network of institutions in charge of global governance, whose very objective is to provide a framework for common directions to be discussed, global norms and standards to be set and regulatory bodies to be established. As we have argued, these institutions of global governance are where this patient process of multi-actor discussion and norm-setting ought to take place.

\section{A Davos summit for global public policies}

Progress on the coherence of international cooperation initiatives will depend on the progress of global governance. Although much remains to be done to consolidate its role, the birth of the G20 is no doubt an important step forward in adapting global governance processes to $21^{\text {st }}$ century realities. However the G20 will never include the non-state actors that increasingly drive global public policies. No place allows governments, NGOs, think tanks and the private sector to discuss global issues in a structured way: neither the United Nations, the OECD, the Bretton Woods institutions nor the Global compact can claim this role. Building and structuring this

${ }^{79}$ SEVERINO, JM. (2007), Millennium Development Goals: Looking Beyond 2015. Blog on ID4D.org 
dialogue could help shaping the discourses that will move the collective discussion forward in finding collective solutions to $21^{\text {st }}$ century challenges.

The Davos 'World Economic Forum' and the 'World Social Forum' have taken on important roles in recent years. Every year, they keep the momentum on crucial elements of the global economic and social agendas. They allow for very different actors involved in the corporate or non-governmental communities to meet, cross perspectives and gather around collective interests.

Global public policies could have their own annual forum. They are not in need of yet another high-level summit where heads of state sign bulky treaties and read out pre-negotiated speeches, but rather of an open forum covering the whole spectrum of global public policies. This forum would bring together the diverse actors of international cooperation (NGOs, bilateral and multilateral organisations, foundations, think tanks, the media, etc.), and thus give an occasion to exit the policy silos in which each section of international cooperation menaces to embark.

Such meetings would progressively help crystallise coalitions of actors around common topics of interest. They would also provide platforms for new ideas to be voiced, evaluation results to be shared, and innovative schemes to find funding. This mutli-actor discussion would gradually help a common objective function to emerge for global public policies.

\section{Conclusion}

Adapting $20^{\text {th }}$ century institutions of global governance to $21^{\text {st }}$ century hypercollective action is a huge challenge, for which no silver bullet will be found. While it did not aim to offer solutions, we hope that this exploratory journey in the world of global public policies has helped uncover some of the systemic causes for the persistent difficulties in reaching effective international collective action - causes that are often overlooked when devising policy responses.

Our intuition is that the long road towards effective hypercollective action is full of wrong turns that risk extending the journey considerably - as well as its cost. In the era of global public policies, international policymakers ought to stay clear of traditional solutions to invent a new generation of collaborative processes more compatible with the new political economy of global public policies as they are shaping up in these early years of the $21^{\text {st }}$ century. If there is any hope in brining more coherence to the chaos that characterises international cooperation initiatives, we believe that it will be through the patient knitting of the five modes of collaboration that we have identified as constituting the fabric of effective hypercollective action: rules and engagements, norms and standards, systems of incentives, information and discourses as well as networks and partnerships.

If this is true, then the road map begins to clarify. Although the measures suggested above are far from sufficient, concrete actions can be taken to:

- progressively expand the scope of the Paris Declaration process to deliver on other global public policies than traditional development aid, while shifting the focus away from rules and norms of 'harmonization' towards processes of convergence;

- devise incentives for cooperation - which implies turning multilateral actors into funders and rewarders of convergence;

- imagine 'sticks' to give teeth to the coherence agenda, for instance by spreading 'global' evaluation through the intermediary of an evaluation platform; 
- create common standards of measurement, which would allow for the measure of traditional development aid to converge with the measures of global policy finance;

- inform the policy by creating common public information campaigns and cognitive frameworks, which could be confronted in yearly 'Davos summits' of global policies. 